\title{
Rho-Proteins and Downstream Pathways as Potential Targets in Sepsis and Septic Shock: What Have We Learned from Basic Research
}

\author{
Maria Luísa da Silveira Hahmeyer and José Eduardo da Silva-Santos *
}

\author{
Laboratory of Cardiovascular Biology, Department of Pharmacology, Universidade Federal de Santa Catarina, \\ Florianópolis 88040-900, SC, Brazil; mlhahmeyer@gmail.com \\ * Correspondence: j.e.silva.santos@ufsc.br; Tel.: +55-48-3721-4847
}

Citation: Hahmeyer, M.L.d.S.; da Silva-Santos, J.E. Rho-Proteins and Downstream Pathways as Potential Targets in Sepsis and Septic Shock: What Have We Learned from Basic Research. Cells 2021, 10, 1844. https://doi.org/10.3390/cells 10081844

Academic Editors: Igor Weber and Vedrana Filić

Received: 16 June 2021

Accepted: 15 July 2021

Published: 21 July 2021

Publisher's Note: MDPI stays neutral with regard to jurisdictional claims in published maps and institutional affiliations.

Copyright: (C) 2021 by the authors. Licensee MDPI, Basel, Switzerland. This article is an open access article distributed under the terms and conditions of the Creative Commons Attribution (CC BY) license (https:// creativecommons.org/licenses/by/ $4.0 /)$.

\begin{abstract}
Sepsis and septic shock are associated with acute and sustained impairment in the function of the cardiovascular system, kidneys, lungs, liver, and brain, among others. Despite the significant advances in prevention and treatment, sepsis and septic shock sepsis remain global health problems with elevated mortality rates. Rho proteins can interact with a considerable number of targets, directly affecting cellular contractility, actin filament assembly and growing, cell motility and migration, cytoskeleton rearrangement, and actin polymerization, physiological functions that are intensively impaired during inflammatory conditions, such as the one that occurs in sepsis. In the last few decades, Rho proteins and their downstream pathways have been investigated in sepsis-associated experimental models. The most frequently used experimental design included the exposure to bacterial lipopolysaccharide (LPS), in both in vitro and in vivo approaches, but experiments using the cecal ligation and puncture (CLP) model of sepsis have also been performed. The findings described in this review indicate that Rho proteins, mainly RhoA and Rac1, are associated with the development of crucial sepsis-associated dysfunction in different systems and cells, including the endothelium, vessels, and heart. Notably, the data found in the literature suggest that either the inhibition or activation of Rho proteins and associated pathways might be desirable in sepsis and septic shock, accordingly with the cellular system evaluated. This review included the main findings, relevance, and limitations of the current knowledge connecting Rho proteins and sepsis-associated experimental models.
\end{abstract}

Keywords: endotoxemia; endotoxic shock; organ dysfunction; Ras proteins; small GTPases

\section{Introduction}

Sepsis is defined as life-threatening organ dysfunction caused by a dysregulated host response to infection, as introduced by the Third International Consensus Definitions for Sepsis and Septic Shock in 2016 [1]. The clinical management and criteria for the early diagnosis of sepsis and septic shock have been systematically reviewed since the 1990s, implementing significant advances in prevention, treatment, and survival rates associated with these conditions. Nevertheless, sepsis remains a global health problem and a significant cause of mortality, accounting for around 20\% of worldwide deaths in 2017 [2]. The knowledge regarding the onset and prognosis of sepsis remains under ongoing discussion, but it depends on associated risk factors and underlying conditions. The elderly, young children, and immunocompromised individuals are examples of people included in risk groups, and serum levels of pro-inflammatory and anti-inflammatory cytokines have been explored to predict fatal outcomes in septic patients [3]. Indeed, one of the primary reasons sepsis is hard to be predicted and treated is its complex pathophysiology, which includes almost all known inflammatory mediators, differentially found in distinct tissues and stages of the disease. The acute or sustained impairment in vital systems can compromise the kidneys, lungs, liver, coagulation, and central nervous system, among others. Notably, 
the cardiovascular system is affected from early to late stages of sepsis, and the dysfunction in several organs may be at least partially resulted from reduced blood perfusion and augmented vascular permeability, which are hallmarks with putative clinical value for the prognosis of this condition [4]. In the vascular system, high levels of reactive oxygen species (ROS), including nitric oxide (NO), are produced, beginning in the very early stages of sepsis, triggering endothelial dysfunction. The unbalanced production of endothelial mediators and exacerbated levels of inflammatory cytokines contribute to persistent hypotension, leading to the inadequate blood supply and poor tissue perfusion, reducing $\mathrm{O}_{2}$ distribution. Sepsis progresses to septic shock when physiological mechanisms and fluid resuscitation are unable to restore blood pressure, the patient presents hyperlactatemia (>2 mmol/L), and vasopressor drugs are required to maintain the minimum $65 \mathrm{~mm} \mathrm{Hg}$ mean arterial pressure. In more severe stages, the vascular system became hyporeactive to vasoconstrictors, and the desired arterial pressure cannot be targeted even when high doses of pressor agents are used [1]. For this, components of the cardiovascular system may be considered crucial targets to prevent sepsis-associated organ dysfunction.

The discovery of small $\mathrm{G}$ proteins, followed by the description of their widespread distribution and biological properties, raised an unexplored field for drug targets with putative importance in several diseases, including sepsis and septic shock. The Rho subfamily is part of the Ras superfamily of small GTPases, and is composed of 20 members in mammalians, further subdivided into eight different subclasses (i.e., Rho, Rac, Cdc42). Rho proteins have been broadly studied in several areas, such as the regulation of cell migration [5], calcium sensitization, and the maintenance of smooth muscle tone, i.e., [6,7], differentiation [8], cell growth and apoptosis [9], regeneration [10], focal adhesion [11,12] and polarity [13,14], cytokinesis $[15,16]$, and membrane trafficking and ruffling [17,18], among others. Recent studies have also suggested that Rho-GTPase signaling pathways crosstalk with each other and are influenced by cellular mechanics, leading to the self-organization of several dynamic cellular processes (for reviews, see [19-21]). The involvement of Rho proteins in so many cellular functions explains why these small $\mathrm{G}$ proteins and their downstream pathways have a pivotal role in both physiological and pathological conditions.

Rho proteins are small GTPases that switch between active and inactive stats, dependent on GTP or GDP biding, respectively, a process regulated by guanine nucleotide exchange factors (GEFs), GTPase-activating proteins (GAPs), and guanine nucleotide dissociation inhibitors (GDIs). Similar to classical heterotrimeric $G$ proteins, Rho proteins are also subjected to activation by different subtypes of transmembrane receptors classified as G protein-coupled receptors (GPCRs). However, unlike heterotrimeric G proteins, the mechanisms throughout GPCRs activate Rho proteins are indirect and dependent on GEFs. Moreover, it mainly includes receptors coupled to $\mathrm{G}$ proteins containing the $\alpha_{\mathrm{q}}$ and $\alpha_{12 / 13}$ subunits, i.e., [22,23]. Several receptors with key regulatory effects in the vascular smooth muscle cells (i.e., $\alpha_{1}$-adrenoceptors and angiotensin II AT1 receptors), endothelium (i.e., bradykinin B2 receptors), and platelets (i.e., protease-activated receptor-1, PAR-1) are coupled to $G \alpha_{q}$ and $G \alpha_{12 / 13}$ proteins. Importantly, these GPCRs have been used or at least investigated as drug targets in the management of sepsis. Besides, Rho proteins are also reached by other classes of receptors, such as integrin [24] and peroxisome proliferator-activated receptors [25], reinforcing their multiple regulatory roles in cell signaling.

Rho proteins can interact with a considerable number of targets, regulating multiple processes that are all subjected to pathological or adaptive changes with functional relevance during inflammatory processes, such as the one that occurs in septic insults. We aim to provide the readers with a comprehensive overview to allow the understanding of how the study of Rho proteins and their downstream pathways, particularly the Rho-associated coiled-coil-containing protein kinase (Rho-kinase or ROCK, further classified as subtypes I and II), are directly or indirectly involved in different signs or symptoms of this disease, and perhaps why it can be a source of innovative targets for the clinical management of 
sepsis and septic shock. As summarized in Figure 1 and explored ahead, Rho proteins and Rho-associated targets are involved in the main signs of sepsis and septic shock.
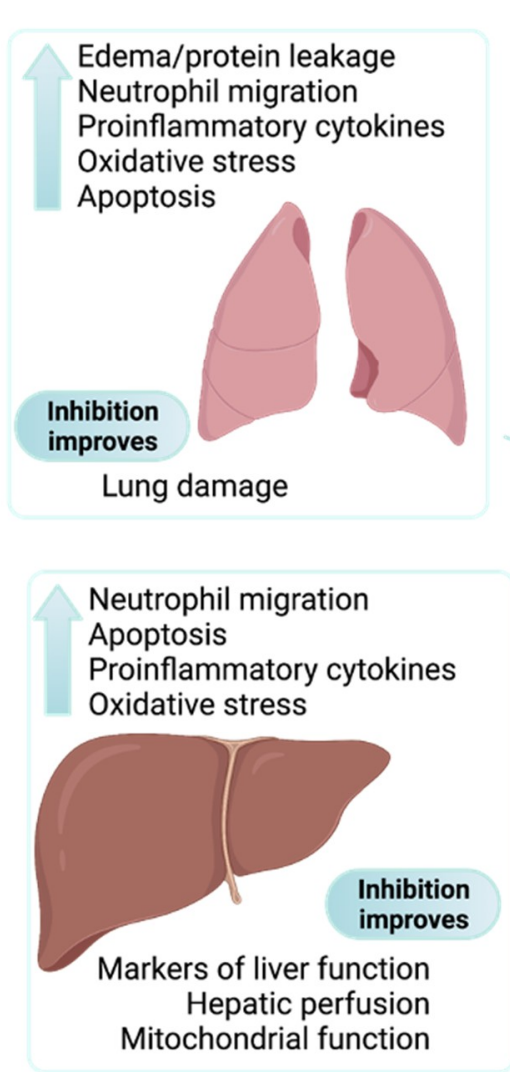

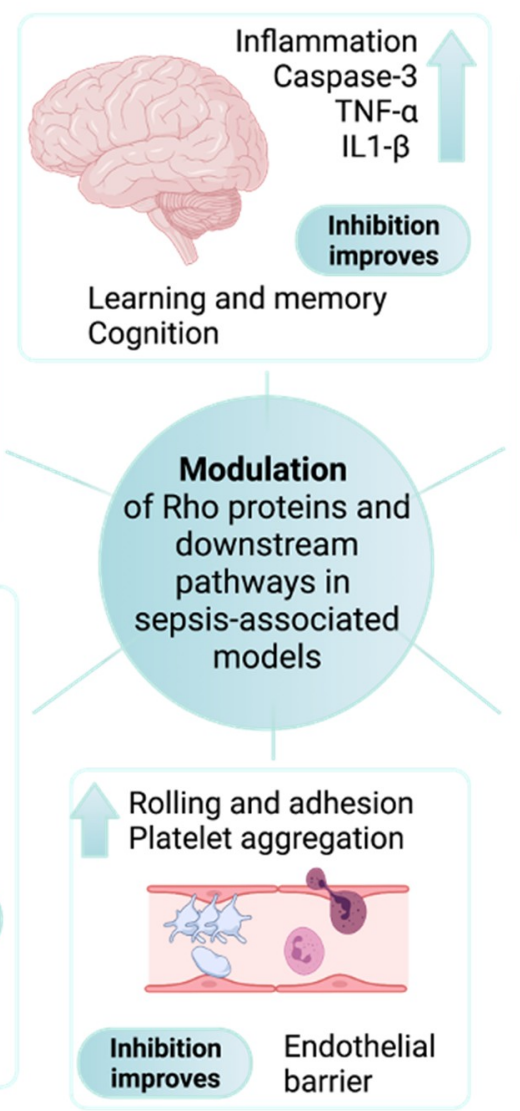

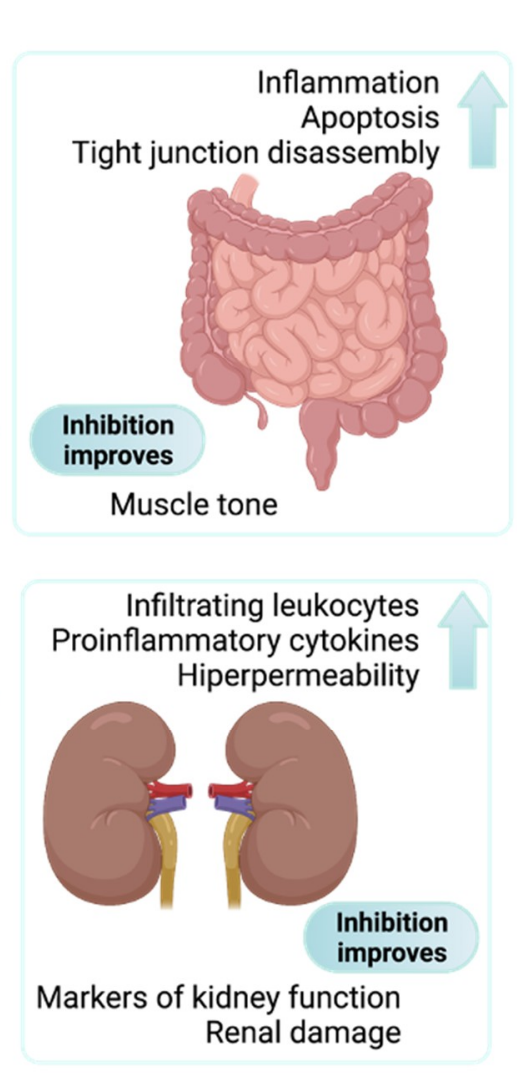

Figure 1. Main findings associated with the modulation of Rho proteins and downstream pathways in sepsis-associated experimental models. Although different Rho proteins have been explored in in vitro experimental approaches, all parameters presented inside each box were described in studies performed on animals subjected to sepsis models and treated with selective inhibitors of ROCK. Findings associated with sepsis-induced organ dysfunction are shown next to the up arrow. The main beneficial effects ascribed to inhibition of the RhoA/Rho-kinase pathway are included at the bottom of each box.

\section{Experimental Models Used to Study Sepsis-Associated Dysfunctions}

Sepsis and septic shock are systemic conditions that gradually affect all vital functions in humans and animals. The complexity of such effects, the intensive supporting care, fluid replacement, and multiple drugs used, including but not limited to antibiotic therapy, vasopressor, and inotropic agents, creates a scenario that is virtually impossible to be entirely replicated in laboratory studies. Notably, our knowledge about how sepsis impairs human physiology has been built under the light of approaches that attempt to reproduce at least part of the infection or inflammatory process that occurs in this condition. For instance, although it cannot be defined as experimental models of sepsis, proinflammatory cytokines, mainly the tumor necrosis factor (TNF)- $\alpha$ and interleukin (IL)- $1 \beta$ have been used to create the inflammatory environment in studies focused on sepsis.

Bacterial lipopolysaccharide (LPS) has been used in in vitro and in vivo studies. It can reproduce much of the inflammation-associated responses found in cells, tissues, and entire animals, such as the production of proinflammatory cytokines, impaired metabolism or muscle contractility, hypotension, and low blood perfusion. The main limitations of LPS as an experimental model for the study of sepsis-associated events are the lack of an ongoing infection, the self-limited duration of the effect when used in in vivo studies, and its action centered on the activation of the Toll-like receptor (TLR) 4. Although the status of 
LPS as a reliable experimental model of sepsis remains under discussion [26], the challenge with LPS allows the investigation of sepsis-associated responses in cultured cells under very controlled conditions. Indeed, it is widely used and can be considered an excellent choice for the study of cell signaling intracellular processes putatively impaired by sepsis.

Additional models for the study of sepsis include the cecal ligation and puncture (CLP), the intraabdominal injection of fecal pellets, and the administration of pathogenic microorganisms [27-30]. Among these, the CLP model, which consists of a controlled injury in the cecum that generates polymicrobial sepsis, has been described as the golden model in terms of similarity with the temporal course and organ dysfunction that occurs in septic shock in humans [26,28].

In this review, we discuss the results obtained from in vitro and in vivo studies that explored the behavior of Rho proteins and related intracellular signaling pathways in experimental conditions potentially associated with sepsis, mainly LPS challenge and stimulation with proinflammatory cytokines. Whenever performed, studies using the induced sepsis model were included in our description.

\section{Rho Proteins and Their Impact on Endothelial Function in Sepsis-Related Experimental Approaches}

The relationship between changes in endothelial function and sepsis is narrow. The exacerbated inflammation that occurs in sepsis leads to endothelial dysfunction, which in this condition is characterized by the unbalanced production of endothelial factors crucial for several physiological events, including the maintenance of the own endothelial biology, preservation of the endothelial barrier function, prevention of blood clotting, and the regulation of the vascular tone. As summarized in Table 1, the involvement of Rho proteins in sepsis-associated endothelial dysfunction has been continuously investigated.

One of the first pieces of evidence that the RhoA/ROCK pathway could play a role in the pathophysiology of sepsis was the demonstration of reduced activity of myosin light chain phosphatases (MLCP) and enhanced myosin light chain (MLC) phosphorylation in human endothelial cells incubated with LPS, which was counteracted by inhibitors of ROCK and cAMP [31]. This augmented activation of Rho components can contribute to endothelial contraction and vascular leakage in sepsis, as shown in both LPS-treated and CLP-subjected animals [32-36]. Among the mechanisms associating Rho protein and endothelial barrier disruption, the activation of RhoA and/or ROCK in response to LPS were involved in in vivo leukocyte adhesion in femoral [32] and hepatic [37] arteries of mice, the loss of VE-cadherin function in endothelial cells [38-40], increased expression of adhesion molecules [40], and neutrophil-endothelial adhesion [41].

RhoA has previously been described as susceptible to inhibitory regulation by Rac [42]. Thus, the delicate balance between the antagonistic effects of Rac and RhoA activities is a potential target for regulating the endothelium barrier function in sepsis, as suggested by the anti-permeability effect of angiopoietin- 1 in both endothelial cells and mice exposed to LPS [43]. Nevertheless, this is a multicomplex process that involves the entire contractile machinery in the endothelial cells, as explored by Bogatcheva and co-workers, who also found that the inhibition of ROCK can either improve or worsen the barrier function of human lung microvascular endothelial cells [44]. Accordingly, the activation of RhoA by the active biolipid sphingosine-1-phosphate was suggested as an important way to counteract pericyte loss and improve barrier function in endothelial cells subjected to LPS [45]. Moreover, both the activation and inactivation of endothelial Rho by Clostridium limosum exoenzyme and Escherichia coli cytotoxic necrotizing factor CNF1, respectively, improved the endothelial barrier, reducing leukocyte migration [46]. Additionally, Adamson and co-workers described that the inhibition of ROCK reduced the basal unstimulated vascular permeability in rat venular microvessels of the mesentery but failed to prevent the transient permeability induced by bradykinin and platelet-activating factor [47]. Besides, augmented levels of active Rac1 and Cdc43, and unaltered RhoA, were detected in CNF1-stimulated myocardial endothelial cells [48]. 
Despite the few studies detailing how LPS or sepsis modulate Rho proteins in endothelial cells, the effects of endogenous molecules that are increased under LPS or septic insults, such as thrombin [49], heparin-binding protein [50], and the heat-shock protein 90 [51], have been linked with Rho-dependent mechanisms. Additionally, there is substantial evidence that the engagement of Rho proteins in endothelial barrier regulation can be dependent on the kind of vessel or cell evaluated [52-54]. For instance, the activation of Rho was necessary for TNF- $\alpha$-mediated barrier dysfunction in human lung microvascular endothelial cells [55] and umbilical vein endothelial cells [56], but only Rac accounts for this effect in human dermal microvascular endothelial cells [57]. Indeed, the role of Rho proteins on endothelial hyperpermeability depends on both the inflammatory mediator [58] or the time point evaluated [59]. In any case, endothelial dysfunction has a putative causal relationship with infections and inflammatory processes, which also can be modulated by Rho proteins $[60,61]$. In this way, the activation of the TLR 4 by LPS upregulated the guanine-nucleotide exchange factor GEF-H1 and increased the activity of RhoA in human umbilical vein endothelial cells, and this process was characterized as an upstream step for nuclear factor kappa B (NF- $\mathrm{KB})$ transactivation and interleukin (IL)-8 expression [62]. Interestingly, the activation of GEF-H1 and NF- $\mathrm{kB}$ were also found in Staphylococcus aureus-induced endothelial barrier dysfunction [63]. Furthermore, the inhibition of ROCK significantly reduced LPS-increased inflammatory cytokines IL- $1 \beta$ and IL-6 in human lung microvascular endothelial cells, at least partly via NF-KB inhibition [64]. Similar findings associating the RhoA pathway and the NF- $\mathrm{BB}$ activity with LPS-induced endothelial hyperpermeability were also previously described in mouse brain-derived microvascular endothelial cells [65].

Mediators produced by the endothelial cells, including NO, metabolites of arachidonic acid, and ROS, are often involved in the control of vascular tone. However, they are also crucial to regulate the endothelial barrier, platelet aggregation, and the expression of adhesion molecules, among others. Transgenic mice expressing CYP2J2, the cytochrome P450 epoxygenase 2J2 that produces epoxyeicosatrienoic acids, presented reduced mortality rates when treated with lethal doses of LPS. This protection was explained by the ability of epoxyeicosatrienoic acids to inhibit the generation of ROS and the subsequent activation of the RhoA/ROCK pathway in endothelial cells, preventing MLC phosphorylation and improving the endothelial barrier [66].

The widespread presence of the nitric oxide synthase (NOS) among mammalian cells makes $\mathrm{NO}$ a key mediator in several systems. Notwithstanding the multiple physiological roles of NO, the nature of its effects on cellular biology are entirely dependent on the amounts produced. Along with inflammatory burst that occurs in sepsis, the overexpression of the inducible isoform of NOS (iNOS) exacerbates the vasodilatory and hypotensive effects generated by NO, contributing to the reduced blood flow and the organ damage seen in this condition. Although strategies capable of preventing or reversing the harmful effects of NO remain desirable, maintaining the activity of endothelial NOS (eNOS) might be essential for vascular recovery in sepsis. Notably, the administration of the ROCK inhibitor fasudil prevented the overexpression of iNOS and increased the levels of eNOS in mesenteric endothelial cells from rats treated with LPS, an effect accompanied by a reduction in both macromolecular leak and leukocyte adhesion in mesenteric arteries [67]. The dependence of eNOS for the anti-inflammatory and antiapoptotic effects obtained after the inhibition of the RhoA/ROCK pathway in LPS-treated endothelial cells was also described [68]. Endothelium-derived mediators keep an orchestrated equilibrium to maintain vascular functions. Under physiological conditions, endothelin-1, a potent vasoconstrictor, also promotes the vascular release of $\mathrm{NO}[69,70]$. This function can be disrupted under inflammatory stimuli, such as LPS, but the pharmacological inhibition of the RhoA/ROCK pathway was able to bring back endothelin-1-mediated eNOS activity [71]. Regarding advances into the molecular regulatory mechanisms on Rho proteins, peroxynitrite-mediated RhoA and Rac1 nitration [72,73] were proposed as a key event driving the increment and 
inhibition of RhoA and Rac1 activities, respectively, which contributes to LPS-induced endothelial barrier disruption.

Regardless of the missing points that would enhance our comprehension about how the function of Rho proteins and its up or downstream targets are modulated in endothelial cells during septic insults, these small $\mathrm{G}$ proteins have been consistently included in the physiological regulation of endothelial structure and function in different vascular systems [74-87]. In summary, the balanced activity of Rho proteins has been reported as mandatory to maintain several aspects of endothelial biology, including F-actin stabilization, contractility, and functional tight junctions (Figure 2A). This balance is disrupted when endothelial cells are subjected to a proinflammatory environment such as the one found in sepsis, resulting, for instance, in the reduced activity of Rac1 and augmented activity of the RhoA pathway, which contribute to endothelial dysfunction (Figure 2B). Notably, the direct or indirect modulation of these proteins by GEFs, i.e., [88,89], chemical compounds, i.e., [90-92], endogenous mediators, i.e., [45,56,93,94], or even RNA manipulation, i.e., $[62,63,95]$, may provide additional insights about the putative role of Rho proteins in the endothelial function in sepsis (see Table 1).

Table 1. The involvement of Rho proteins and downstream pathways in the endothelial function as found in sepsisassociated experimental models.

\begin{tabular}{|c|c|c|c|c|}
\hline System and Model & Component(s) Evaluated & Experimental Setup & Impact on the System and Main Findings ${ }^{a}$ & Ref. \\
\hline \multirow[t]{5}{*}{$\begin{array}{l}\text { HLMVEC; } \\
\text { LPS }\end{array}$} & Rac1, RhoA & $\begin{array}{l}\text { Indirect modulation + siRNA } \\
\text { (includes in vivo evaluation) }\end{array}$ & $\begin{array}{l}\text { Activation of Rac1 and inhibition of RhoA } \\
\text { prevents vascular leakage; stabilizes }\end{array}$ & [43] \\
\hline & ROCK & Direct inhibition + siRNA & $\begin{array}{c}\text { VE-cadherin. } \\
\text { ROCK can prevent or enhance vascular } \\
\text { leakage. }\end{array}$ & [44] \\
\hline & RhoA & $\begin{array}{l}\text { Direct inhibition + siRNA } \\
\text { (includes in vivo evaluation) }\end{array}$ & $\begin{array}{c}\text { Inhibition of RhoA nitration prevents } \\
\text { vascular leakage. }\end{array}$ & [72] \\
\hline & RhoA, ROCK & $\begin{array}{l}\text { Indirect modulation + direct } \\
\text { inhibition }\end{array}$ & $\begin{array}{c}\text { Inhibition of RhoA/ROCK prevents vascular } \\
\text { leakage. }\end{array}$ & [51] \\
\hline & Rac1 & $\begin{array}{c}\text { Direct modulation } \\
\text { (includes in vivo evaluation) }\end{array}$ & $\begin{array}{l}\text { Prevention of Rac1 nitration limits vascular } \\
\text { leakage. }\end{array}$ & [73] \\
\hline $\begin{array}{l}\text { HLMVEC; } \\
\text { LTA + PepG }\end{array}$ & MCLP, MLC & $\begin{array}{l}\text { Direct inhibition } \\
\text { (includes in vivo evaluation) }\end{array}$ & $\begin{array}{c}\text { Inhibition of ROCK prevents vascular } \\
\text { leakage. }\end{array}$ & [53] \\
\hline $\begin{array}{l}\text { HLMVEC; } \\
\text { TNF- } \alpha\end{array}$ & RhoA, ROCK & Direct inhibition & $\begin{array}{l}\text { Inhibition of RhoA/ROCK pathway prevents } \\
\text { vascular leakage. }\end{array}$ & [55] \\
\hline \multirow[t]{9}{*}{$\begin{array}{l}\text { HUVEC; } \\
\text { LPS }\end{array}$} & MLC, pMLC & Direct inhibition & $\begin{array}{c}\text { Inhibition of ROCK prevents vascular } \\
\text { leakage. }\end{array}$ & [31] \\
\hline & RhoA, GEF-H1 & iRNA & $\begin{array}{l}\text { Reduction in RhoA activation disfavor } \\
\text { inflammatory pathway. }\end{array}$ & [62] \\
\hline & RhoA, MLCP & siRNA & $\begin{array}{l}\text { RhoA inhibition prevents vascular leakage } \\
\text { and stabilizes VE-cadherin. }\end{array}$ & [39] \\
\hline & ROCK, RhoA, MLCP & $\begin{array}{l}\text { Direct inhibition } \\
\text { (includes in vivo evaluation) }\end{array}$ & $\begin{array}{c}\text { Inhibition of ROCK prevents vascular } \\
\text { leakage. }\end{array}$ & [66] \\
\hline & ROCK, GEF-H1 & Direct inhibition + siRNA & $\begin{array}{l}\text { Inhibition of ROCK and GEF-H1 prevents } \\
\text { vascular leakage, stabilizes adherens and } \\
\text { tight junctions. }\end{array}$ & [89] \\
\hline & RhoA, Rac, Cdc42 & Indirect modulation + siRNA & $\begin{array}{c}\text { Inhibition of RhoA and Rac prevents vascular } \\
\text { leakage, stabilizes junctions, and disfavors } \\
\text { inflammation. }\end{array}$ & [92] \\
\hline & RhoA & Direct inhibition & $\begin{array}{l}\text { Inhibition of ROCK prevents vascular } \\
\text { leakage and stabilizes VE-cadherin. }\end{array}$ & [40] \\
\hline & ROCK & $\begin{array}{l}\text { Indirect modulation + direct } \\
\text { inhibition }\end{array}$ & $\begin{array}{l}\text { Downregulation of ROCK disfavor } \\
\text { inflammatory pathway. }\end{array}$ & [90] \\
\hline & RhoA, ROCK & Direct inhibition + siRNA & $\begin{array}{c}\text { Inhibition of ROCK reduces stress fiber } \\
\text { formation. }\end{array}$ & [91] \\
\hline $\begin{array}{l}\text { HUVEC; } \\
\text { TNF- } \alpha\end{array}$ & RhoA, ROCK, MLCP & Indirect modulation & $\begin{array}{l}\text { Inhibition of ROCK prevents vascular } \\
\text { leakage and stabilizes VE-cadherin. }\end{array}$ & [56] \\
\hline $\begin{array}{l}\text { HUVEC; } \\
\text { HBP }\end{array}$ & ROCK & $\begin{array}{l}\text { Indirect modulation + direct } \\
\text { inhibition }\end{array}$ & $\begin{array}{c}\text { Inhibition of ROCK prevents vascular } \\
\text { leakage. }\end{array}$ & [50] \\
\hline $\begin{array}{l}\text { HVEC; } \\
\text { thrombin }\end{array}$ & RhoA, ROCK & Indirect modulation + siRNA & $\begin{array}{l}\text { Inhibition of ROCK prevents vascular } \\
\text { leakage, stabilizes VE-cadherin, reduces } \\
\text { stress fiber formation. }\end{array}$ & [49] \\
\hline
\end{tabular}


Table 1. Cont.

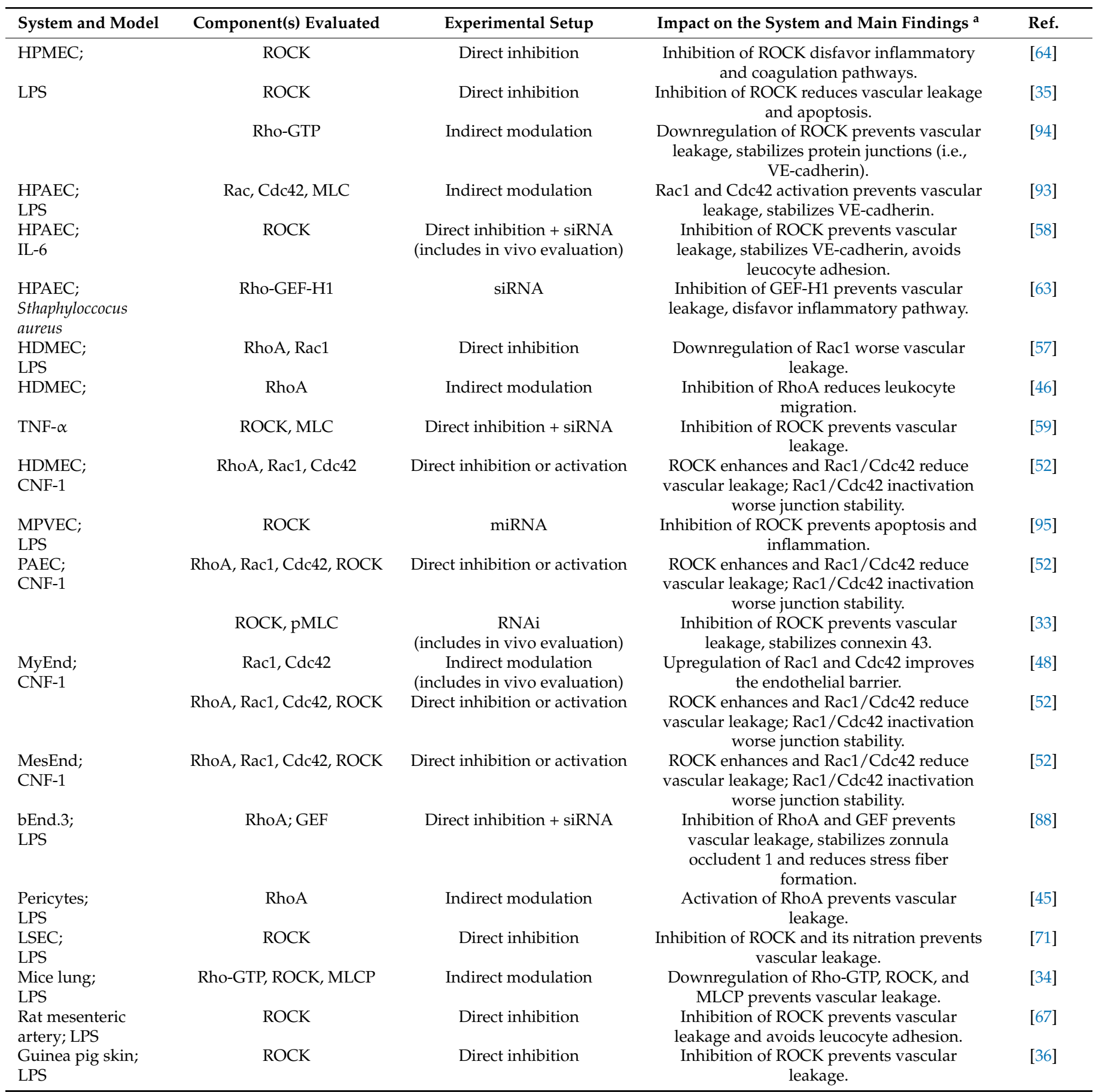

${ }^{a}$ : only those conclusions directly associated with Rho proteins were included. Abbreviations: bEnd.3, mouse brain endothelial cells; CLP, cecal ligation and puncture; CNF-1, Escherichia coli cytotoxic necrotizing factor 1; HBP, heparin-binding protein; HDMEC, human dermal microvascular endothelial cells; HLMVEC, human lung microvascular endothelial cells; HPAEC, human pulmonary artery endothelial cells; HPMEC, human pulmonary microvascular endothelial cells; HUVEC, human umbilical vascular endothelial cells; LSEC, liver sinusoidal endothelial cells; LPS, lipopolysaccharide; LTA, lipoteichoic acid; MesEnd, microvascular mesenteric endothelial cells; MLC, myosin light chain; MCLP, myosin light chain phosphatase; MPVEC, murine pulmonary microvascular endothelial cells; MyEnd, mouse myocardial endothelial cells; PAEC, porcine aorta endothelial cells; PAF: platelet-activating factor; PepG: Staphylococcus aureus-derived peptidoglycan; pMLC, phosphorylated myosin light chain. 

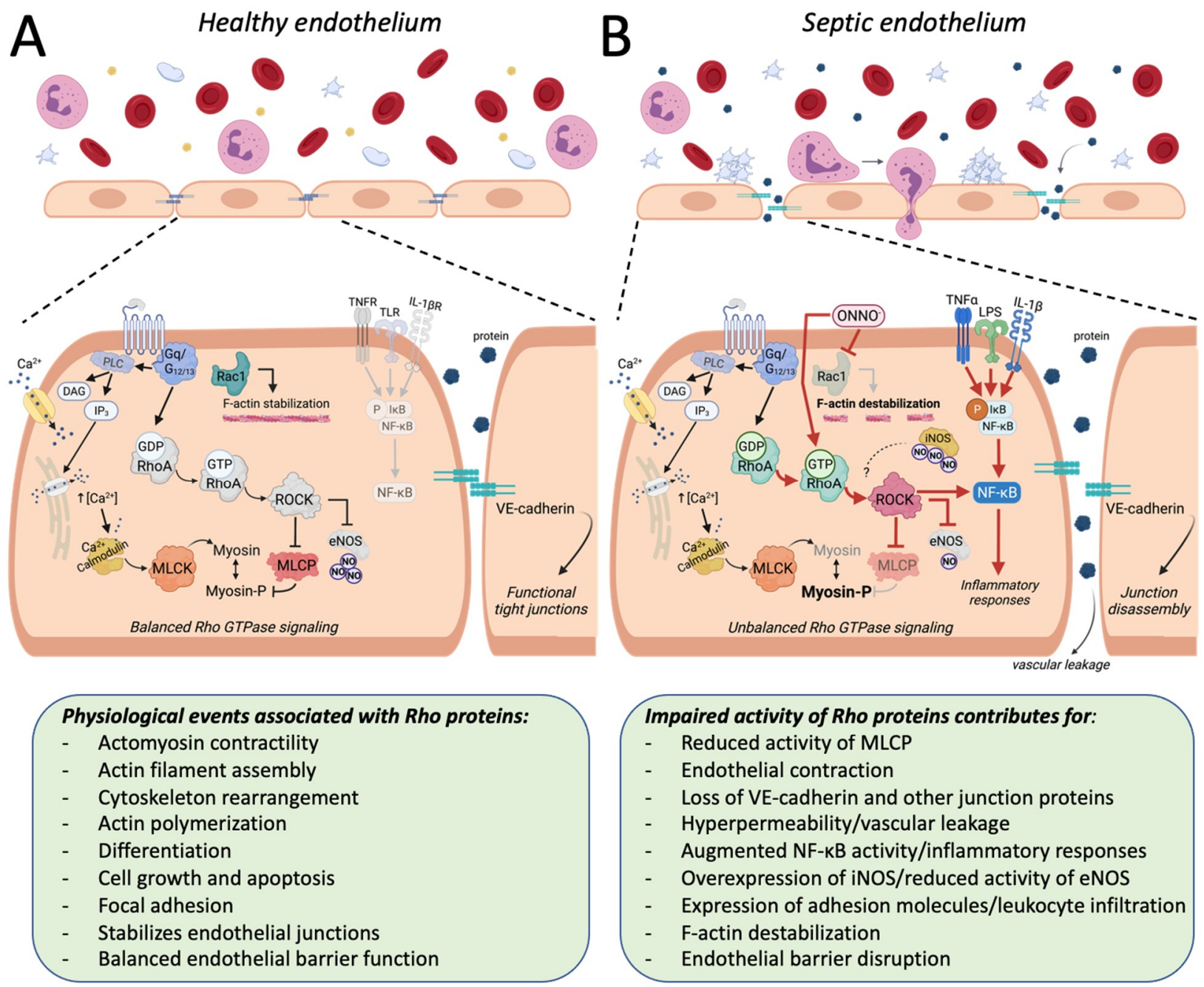

Figure 2. The influence of Rho proteins on the endothelial function in sepsis-associated experimental models. Rho proteins have been involved in several physiological responses. In healthy endothelial cells (A), these responses include Rac1mediated F-actin stabilization and the regulatory effect of the RhoA/ROCK pathway on the activity of enzymes such as the myosin light chain phosphatase (MLCP) and the endothelial nitric oxide synthase (eNOS). The balanced activity of Rho proteins contributes to the maintenance of the endothelial barrier function. Under experimental models of sepsis (B), systemic or locally produced mediators (i.e., ONNO, cytokines) reduce the activity of Rac1 (light gray arrow), contributing to F-actin destabilization, and the activity of the RhoA/ROCK pathway is increased (see the enhanced colors and ticker red arrows), resulting in reduced inhibition of MLCP and augmented levels of phosphorylated myosin (Myosin-P). This unbalanced Rho signaling contributes to exacerbating inflammatory responses, endothelial contraction, loss of junction proteins (i.e., VE-cadherin), endothelial barrier dysfunction, leukocyte infiltration, and vascular leakage, among others. The question mark coming from iNOS in panel B indicates that it remains unclear whether the high amounts of NO produced during septic insults significantly influence the activity of the RhoA/ROCK pathway in endothelial cells. PLC, phospholipase C; DAG, diacylglycerol; IP3, phosphatidylinositol 1,4,5-trisphosphate; MLCK, myosin light chain kinase; TNFR, tumor necrosis factor $\alpha$ receptor; TLR, Toll-like receptor 4 ; IL- $1 \beta R$, interleukin $1 \beta$ receptor.

\section{Rho Proteins and Their Impact on the Vascular Function in Sepsis-Related Experimental Approaches}

The RhoA pathway is particularly important in vascular tone regulation. Briefly, the stimulation of several GPCRs in smooth muscle cells leads to phospholipase C activation, the production of phosphatidylinositol 1,4,5-trisphosphate, and $\mathrm{Ca}^{2+}$ release from the sarcoplasmic reticulum. The augmentation of cytosolic $\mathrm{Ca}^{2+}$ free levels enables calmodulin 
to interact with myosin light chain kinase (MLCK), triggering its activity. The more MLCK is active, the more it phosphorylates the myosin light chain (MLC), which increases its interaction with actin, leading to greater contractility. This process is physiologically contained by myosin light chain phosphatase (MLCP), which dephosphorylates the MLC, reducing the contractile tone. The receptor-mediated activation of RhoA proteins increases the activity of ROCK, which in turn inhibits MLCP. It maintains the cell more susceptible to calcium-mediated MLCK activation. For this, the RhoA/ROCK pathway is defined as a procontraction system and a calcium sensitization route in cell signaling. This physiological role of Rho proteins in vascular muscle cells and its relevance for the maintenance of systemic arterial pressure is illustrated in Figure 3A. It is important to note that tone regulation is not the only physiological function directly modulated by Rho proteins in vascular smooth muscle cells. However, perhaps because the augmented activation of this pathway plays a role in developing hypertensive disorders [7], the most investigated aspect of Rho components in the septic vascular smooth muscle has been its involvement in vascular contractile dysfunction, as can be seen in Table 2.

The incubation of LPS in vascular preparations maintained in organ baths for assessing contractile responses usually results in a pattern of vascular hyporeactivity to vasoactive drugs that resemble the vasoplegia found in septic patients. Using rat pulmonary arteries, Boer and co-workers demonstrated that LPS-induced vascular dysfunction is also characterized by augmented compliance, as evaluated by the diameter of arteries subjected to cumulative stretch, a condition accompanied by a disordered distribution of F-actin in the smooth vascular cells. This disassembly of the F-actin fiber was reproduced by the pharmacological inhibition of ROCK in control vessels (not exposed to LPS) and, most importantly, was preventable by the activation of RhoA in LPS-exposed pulmonary arteries [96].

LPS was found as a negative modulator of the RhoA/ROCK pathway in several studies, i.e., [97]. However, augmented levels of ROCK were also found in endotoxemia, simultaneously to the potentiated contractile responses to endothelin-1, as described in the superior mesenteric artery of rats at $6 \mathrm{~h}$ after LPS administration [98]. Despite the vascular system being treated as a unit, each vascular bed behaves differently depending on the organ evaluated. These differences seem to be particularly important for experimental models of sepsis since the pattern of responses evoked by vasoactive agents depends on the vasculature and time of evaluation [99]. Accordingly, endothelin-1-induced contractile responses and the phosphorylation of MLC were reduced in rat aortic rings at $20 \mathrm{~h}$ after incubation with LPS, but these changes were independent of changes in the RhoA/ROCK pathway [100]. Additionally, the expression levels of Rho pathway components were increased in resistance mesenteric arteries from LPS-treated rats at both early $(6 \mathrm{~h})$ and late $(24 \mathrm{~h})$ periods of endotoxemia, although the vessels were hyporeactive to phenylephrine and more sensitive to ROCK inhibition [101]. Similar findings were described in rat aortic rings at $6 \mathrm{~h}$ after LPS administration [102]. 


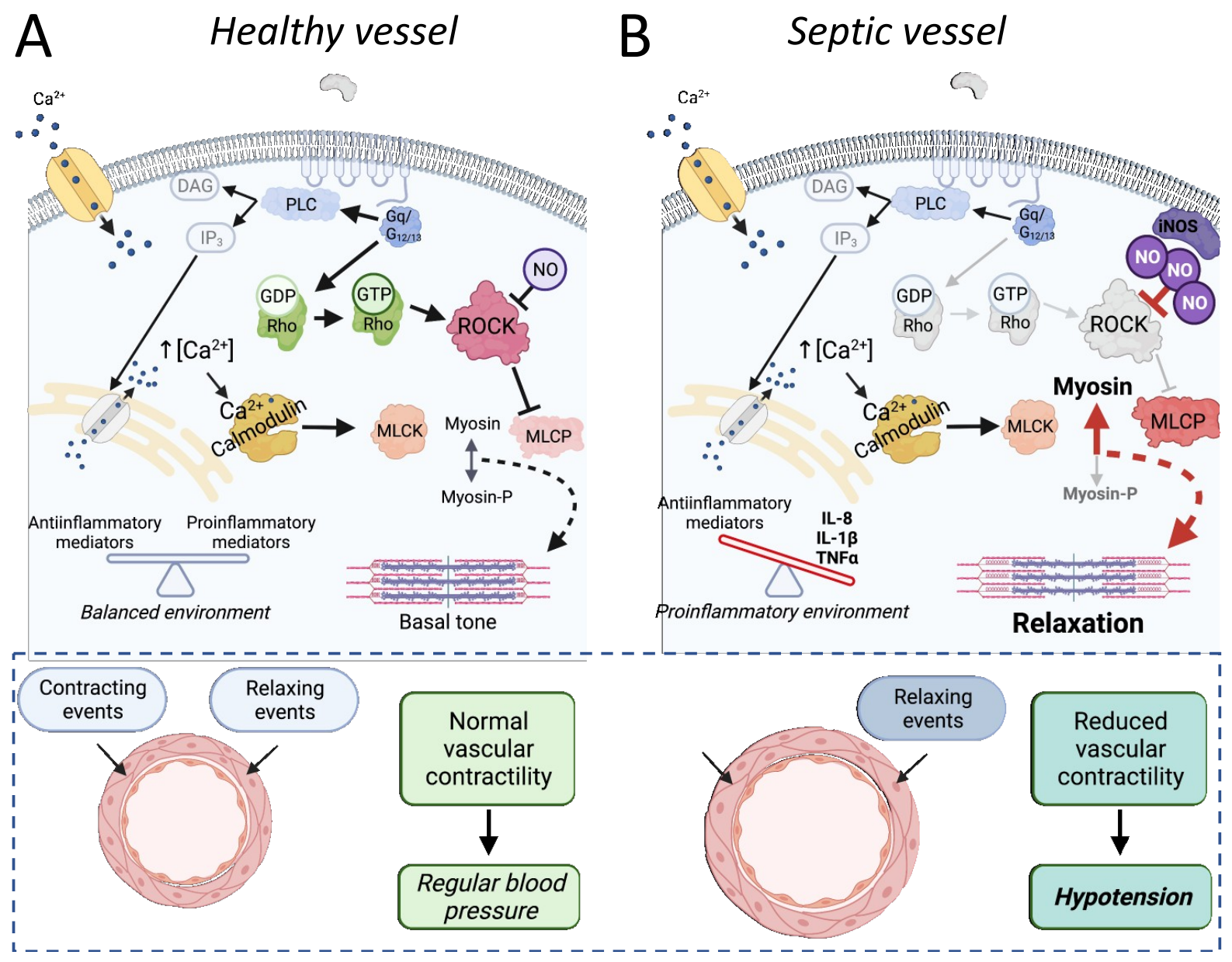

Figure 3. The involvement of Rho proteins in sepsis-associated reduced vascular dysfunction. In healthy vessels (A), activation of the RhoA/ROCK pathway functions as a calcium sensitization mechanism, crucial for regulating vascular tone. Once activated by RhoA, ROCK inhibits the myosin light chain phosphatase (MLCP) activity, maintaining balanced levels of phosphorylated myosin and the vascular tone. Under physiological conditions, there is an equilibrium between contracting and relaxing events, resulting in normal vascular contractility and normal blood pressure. In septic vessels (B), the proinflammatory environment and high levels of nitric oxide, among other factors, reduce the effectivity of Rhomediated calcium sensitization, as illustrated by the grayscale of RhoA/ROCK pathway components and arrows. The final result is an augmented MLCP activity and less phosphorylated myosin (Myosin-P), contributing to the loss of vascular tone and relaxation of vessels. Under septic conditions, the relaxing events are enhanced, and the reduced vascular contractility in resistance arteries is one of the main causes of hypotension. Importantly, the absence of changes in other components included in the scheme (i.e., membrane receptors, calcium levels) does not mean that they are not compromised in sepsis. PLC, phospholipase C; DAG, diacylglycerol; IP3, phosphatidylinositol 1,4,5-trisphosphate; MLCK, myosin light chain kinase.

Although precise mechanisms remain undefined, inflammatory cytokines, high levels of NO, produced mainly by the iNOS isoform, the impaired balance of ROS, and the modulation of downstream targets, such as the soluble guanylate cyclase, potassium and calcium channels, have been described as the main factors responsible for the cardiovascular dysfunction in sepsis. The exposure to either IL-1 $\beta$ and TNF- $\alpha$ caused a concentration-dependent reduction in calcium-induced contraction and decreased the levels of the phosphorylated MLCP in the superior mesenteric artery of rabbits, suggesting that both cytokines can lead to reduced ROCK activity $[103,104]$. We have previously demonstrated that the blocking of NO production and the inhibition of the soluble guanylate cyclase can restore the vascular reactivity and increase the phosphorylation of the MLCP in resistance mesenteric arteries from endotoxemic rats [101]. In fact, at least part of 
the relaxation induced by $\mathrm{NO}$ in both vascular and non-vascular smooth muscles might be due to its inhibitory action on the RhoA/ROCK pathway $[105,106]$. On the other hand, Rho proteins can also regulate the expression of iNOS in vascular smooth muscle cells stimulated by IL-1 $\beta$ [97].

Table 2. The involvement of Rho proteins and downstream pathways in the cardiovascular function as found in sepsisassociated experimental models.

\begin{tabular}{|c|c|c|c|c|}
\hline System and Model & $\begin{array}{l}\text { Component(s) } \\
\text { Evaluated }\end{array}$ & Experimental Setup & $\begin{array}{c}\text { Impact on the System and Main } \\
\text { Findings }{ }^{a}\end{array}$ & Ref. \\
\hline \multirow[t]{2}{*}{$\begin{array}{l}\text { SM artery; } \\
\text { Rats; } \\
\text { LPS }^{b}\end{array}$} & ROCK & $\begin{array}{l}\text { Direct inhibition }+ \\
\text { functional + molecular } \\
\text { approaches }\end{array}$ & $\begin{array}{l}\text { Upregulation of ROCK enhances } \\
\text { contractile responses. }\end{array}$ & [98] \\
\hline & RhoA, ROCK & $\begin{array}{l}\text { Indirect modulation }+ \\
\text { direct inhibition }+ \\
\text { functional + molecular } \\
\text { approaches }\end{array}$ & $\begin{array}{c}\text { RhoA is reduced; activation of the } \\
\text { pathway improves contractile } \\
\text { responses. }\end{array}$ & [110] \\
\hline \multirow[t]{2}{*}{$\begin{array}{l}\text { SM artery; } \\
\text { Rabbits; } \\
\text { IL-1 } \beta^{\mathrm{c}} / \mathrm{TNF}-\alpha^{\mathrm{c}}\end{array}$} & ROCK, MLCP & $\begin{array}{l}\text { Direct inhibition }+ \\
\text { functional + molecular } \\
\text { approaches }\end{array}$ & $\begin{array}{c}\text { Inhibition of ROCK contributes to } \\
\text { IL-1 } \beta \text {-induced vascular } \\
\text { hyporeactivity. }\end{array}$ & [103] \\
\hline & ROCK, MLCP & $\begin{array}{l}\text { Functional + molecular } \\
\text { approaches }\end{array}$ & $\begin{array}{c}\text { Downregulation of ROCK contributes } \\
\text { to TNF- } \alpha \text {-induced vascular } \\
\text { hyporeactivity. }\end{array}$ & [104] \\
\hline $\begin{array}{l}\text { RM artery; } \\
\text { Rats; }\end{array}$ & RhoA, ROCK, MLCP & $\begin{array}{l}\text { Direct inhibition }+ \\
\text { functional }+ \text { molecular }\end{array}$ & $\begin{array}{l}\text { Upregulation of Rho components fails } \\
\text { to trigger contractile responses; }\end{array}$ & [101] \\
\hline LPS $^{b}$ & & approaches & $\begin{array}{l}\text { RhoA/ROCK is inhibited by the nitric } \\
\text { oxide/guanylate cyclase pathway. }\end{array}$ & \\
\hline $\begin{array}{l}\text { Aorta; } \\
\text { Rats; }\end{array}$ & MLC, ROCK & $\begin{array}{l}\text { Functional + molecular } \\
\text { approaches }\end{array}$ & $\begin{array}{l}\text { Hyporeactivity to ET-1 does not } \\
\text { involve the RhoA/ROCK pathway. }\end{array}$ & [100] \\
\hline LPS $^{b}$ & RhoA, ROCK, MLCP & $\begin{array}{l}\text { Direct inhibition }+ \\
\text { functional + molecular } \\
\text { approaches }\end{array}$ & $\begin{array}{l}\text { The activity of RhoA increases } \\
\text { increases }(1-2 \mathrm{~h}) \text { and reduces }(4-6 \mathrm{~h}) \\
\text { after LPS. Norepinephrine-induced } \\
\text { vasoconstriction is more sensitive to } \\
\text { ROCK inhibition. }\end{array}$ & [102] \\
\hline $\begin{array}{l}\text { Aorta; } \\
\text { Rats; } \\
\text { CLP }\end{array}$ & RhoA, ROCK, MLCP & $\begin{array}{l}\text { Direct inhibition }+ \\
\text { functional + molecular } \\
\text { approaches }\end{array}$ & $\begin{array}{l}\text { Upregulation of RhoA and ROCK at } \\
60 \text { days after CLP; augmented } \\
\text { activation of RhoA/ROCK pathway } \\
\text { accounts for enhanced contractile } \\
\text { responses to angiotensin II. }\end{array}$ & [108] \\
\hline $\begin{array}{l}\text { Renal vascular bed and } \\
\text { blood pressure; } \\
\text { Rats; } \\
\text { LPS }^{\text {b }}\end{array}$ & RhoA, ROCK, MLCP & $\begin{array}{l}\text { Direct inhibition }+ \\
\text { functional + molecular } \\
\text { approaches } \\
\text { (includes in vivo } \\
\text { treatment/evaluation) }\end{array}$ & $\begin{array}{l}\text { Increased RhoA/ROCK in the renal } \\
\text { vascular bed accounts for enhanced } \\
\text { pressor responses to vasopressin. }\end{array}$ & [109] \\
\hline $\begin{array}{l}\text { Femoral artery; } \\
\text { Mice; } \\
\text { CLP }\end{array}$ & MLCP & $\begin{array}{l}\text { Functional + molecular } \\
\text { approaches }\end{array}$ & $\begin{array}{c}\text { Thromboxane A2-induced } \\
\text { vasoconstriction and phosphorylation } \\
\text { of MLCP were reduced } 5 \text { days after } \\
\text { CLP. }\end{array}$ & [107] \\
\hline $\begin{array}{l}\text { Pulmonary artery; } \\
\text { Rats; } \\
\text { LPS }^{\text {c }}\end{array}$ & RhoA & $\begin{array}{l}\text { Direct activation }+ \\
\text { molecular approaches }\end{array}$ & $\begin{array}{l}\text { RhoA activation prevents vascular } \\
\text { damage/F-actin rearrangement. }\end{array}$ & [96] \\
\hline $\begin{array}{l}\text { VSMC; } \\
\text { Rats; } \\
\text { LPS/IL-1 } \beta^{c}\end{array}$ & $\begin{array}{c}\text { RhoA, ROCK, Rac1, } \\
\text { MLCP }\end{array}$ & $\begin{array}{l}\text { Direct inhibition }+ \\
\text { molecular approaches }\end{array}$ & $\begin{array}{c}\text { LPS reduces RhoA activity. IL-1 } \beta \\
\text { increases RhoA activity. ROCK } \\
\text { negatively modulates NF- } \mathrm{BB} \text {. }\end{array}$ & [97] \\
\hline $\begin{array}{l}\text { Blood pressure; } \\
\text { Rats; } \\
\text { CLP }\end{array}$ & RhoA, ROCK & $\begin{array}{l}\text { Direct inhibition }+ \\
\text { systemic effects }+ \\
\text { molecular approaches } \\
\quad \text { (includes in vivo } \\
\text { treatment/evaluation) }\end{array}$ & $\begin{array}{l}\text { RhoA/ROCK pathway is } \\
\text { up-regulated; inhibition of ROCK } \\
\text { improves blood pressure. }\end{array}$ & [35] \\
\hline
\end{tabular}


Table 2. Cont.

\begin{tabular}{|c|c|c|c|c|}
\hline System and Model & $\begin{array}{l}\text { Component(s) } \\
\text { Evaluated }\end{array}$ & Experimental Setup & $\begin{array}{c}\text { Impact on the System and Main } \\
\text { Findings }\end{array}$ & Ref. \\
\hline $\begin{array}{l}\text { Cardiomyocytes; } \\
\text { Rats; } \\
\text { LPS }^{\mathrm{c}}\end{array}$ & RhoA & Molecular approaches & $\begin{array}{l}\text { RhoA expression and activity are } \\
\text { further increased by LPS and nitric } \\
\text { oxide in tissues from diabetic animals. }\end{array}$ & [111] \\
\hline $\begin{array}{l}\text { Heart; } \\
\text { Mice; }\end{array}$ & Rac1 & Molecular approaches & $\begin{array}{l}\text { Lack of Rac1 reduces inflammatory } \\
\text { markers, including TNF. }\end{array}$ & [112] \\
\hline LPS ${ }^{b}$ & ROCK & $\begin{array}{c}\text { Direct inhibition }+ \\
\text { functional + molecular } \\
\text { approaches } \\
\text { (includes in vivo } \\
\text { treatment) }\end{array}$ & $\begin{array}{l}\text { Inhibition of ROCK improved } \\
\text { contractile function and mitochondrial } \\
\text { respiration. }\end{array}$ & [113] \\
\hline $\begin{array}{l}\text { Cardiomyocytes and } \\
\text { heart; } \\
\text { Mice; } \\
\text { LPS b,c }\end{array}$ & Rac1 & $\begin{array}{l}\text { Functional + molecular } \\
\text { approaches }\end{array}$ & $\begin{array}{l}\text { Rac1 expression and activity are } \\
\text { increased; lack of Rac1 reduces TNF } \\
\text { and improves cardiac function. }\end{array}$ & [114] \\
\hline $\begin{array}{l}\text { H9C2; } \\
\text { TNF- } \alpha^{c}\end{array}$ & RhoA, Cdc42, Rac1 & $\begin{array}{l}\text { Direct inhibition }+ \\
\text { molecular approaches }\end{array}$ & $\begin{array}{c}\text { TNF- } \alpha \text { increases RhoA, and ROCK } \\
\text { inhibition attenuates mitochondrial } \\
\text { fragmentation. }\end{array}$ & [115] \\
\hline $\begin{array}{l}\text { Heart and } \mathrm{H} 9 \mathrm{C} 2 \\
\text { Rats; } \\
\text { LPS }\end{array}$ & RhoA, ROCK & $\begin{array}{l}\text { Indirect modulation }+ \\
\text { molecular approaches } \\
\text { (includes in vivo } \\
\text { treatment) }\end{array}$ & $\begin{array}{l}\text { RhoA/ROCK proteins are increased, } \\
\text { and the reduction is associated with } \\
\text { improved cardiac function and } \\
\text { reduced apoptosis. }\end{array}$ & [116] \\
\hline $\begin{array}{l}\text { Papillary muscle; } \\
\text { Rats; } \\
\text { CLP }\end{array}$ & ROCK & $\begin{array}{l}\text { Indirect modulation + } \\
\text { functional + molecular } \\
\text { approaches } \\
\text { (includes in vivo } \\
\text { treatment) }\end{array}$ & $\begin{array}{c}\text { Block of ROCK avoids intermedin } \\
\text { 1-53-mediated cardiac troponin I } \\
\text { phosphorylation. }\end{array}$ & [117] \\
\hline
\end{tabular}

${ }^{a}$ : only those conclusions directly associated with Rho proteins were included. ${ }^{b}$ : LPS was administered in vivo (the time for in vitro evaluation varied between studies). ${ }^{c}$ : LPS, IL- $1 \beta$ or TNF- $\alpha$ were incubated in vitro. VSMC, vascular smooth muscle cells. Abbreviations: CLP, cecal ligation and puncture; H9C2, rat cardiomyoblast cells; LPS, lipopolysaccharide; MLC, myosin light chain; MCLP, myosin light chain phosphatase; RM, resistance mesenteric (artery); SM, superior mesenteric (artery).

Rho-associated signaling pathways were also evaluated in animals subjected to the CLP model, and the studies reinforce the idea that the role of Rho proteins and its downstream targets in the pathogenesis of the vascular dysfunction in sepsis also depends on the time, the vascular system, and the vasoactive agents evaluated. For instance, at five days after the septic insult induced by CLP, mice femoral arteries presented unaltered contractile responses to phenylephrine and norepinephrine, but these arteries were less reactive to the thromboxane receptor agonist $\mathrm{U} 46619$ and displayed reduced levels of ROCK-dependent phosphorylation of MLCP [107]. On the other hand, aortas obtained from rats at 60 days after the CLP surgery showed augmented expression levels of RhoA and ROCK and presented enhanced contractile responses to angiotensin II [108], suggesting that Rho proteins and calcium sensitization can be involved in the development of late cardiovascular diseases among patients who survive sepsis. The vasoconstrictor effects of arginine vasopressin and terlipressin, two selective agonists of V1a receptors, a GPCR that stimulates both phospholipase $\mathrm{C}$ and RhoA proteins, were also potentiated in the superior mesenteric arteries of both LPS-treated rabbits and CLP-subjected rats, in a way entirely dependent on ROCK-mediated MLCP phosphorylation [104]. Interestingly, we did previously demonstrate that the enhanced activation of Rho-kinase by vasopressin in the renal vascular bed contributes to the maintenance of the pressor effects mediated by V1a receptors during endotoxemic shock in rats [109].

Understanding the pathophysiological aspects involved in the vascular component during septic shock may allow the development of efficient clinical strategies for the management of severe hypotension and poor blood perfusion, which end up triggering multiple organ failure and high rates of lethality in this syndrome. Unlike endothelial cells, 
from the prism of vascular contractility, most of the experimental studies indicate that sepsis is associated with a depressed functionality of the RhoA/ROCK pathway (Figure 3B), making Rho proteins valuable target candidates (see Table 2 for an overview of the main findings in this topic). For instance, the indirect pharmacological modulation of ROCK by the flavonoid oroxylin-A proved to be able to restore the LPS-induced suppression of RhoA activity in arteries from rats [110]. Nonetheless, the administration of the selective ROCK inhibitor fasudil to rats subjected to the CLP surgery ameliorated acute lung injury, improving several systemic biochemical and inflammatory markers of sepsis severity, including the systemic arterial pressure [35].

\section{Rho Proteins and Their Impact on the Heart Function in Sepsis-Related Experimental Approaches}

The pump heart function is crucial for cardiovascular homeostasis and is also impaired in sepsis, as characterized by reduced left ventricular contractility and deficient relaxation in humans $[118,119]$ and animals, i.e., $[120,121]$. Decreased responsiveness to sympathetic regulation, increased levels of proinflammatory substances, oxidative stress, impaired endothelial function, augmented migration of leukocytes, and mitochondrial dysfunction, among others, have been associated with impaired myocardial contractility, impaired coronary perfusion, and heart arrhythmia in sepsis and septic shock (for review see [122]). Notwithstanding, the detailed interplay between these multiple events remains to be elucidated. Small G proteins are also present in the healthy and diseased hearts, and their multiple functions include the regulation of apoptosis, gene expression, intercellular communication, hypertrophy, and cardiac remodeling, i.e., [123-131].

In recent years, Rho proteins, mainly RhoA and Rac1, have also been involved in sepsisinduced cardiac dysfunction. Soliman and co-workers showed that the levels of RhoA increased in rat ventricular cardiomyocytes after LPS-induced iNOS expression, a process fully reproducible when the cells were incubated with a NO donor, without LPS, indicating that high amounts of NO, such as the amount that occurs in sepsis, can upregulate the RhoA protein in isolated cardiomyocytes [111]. The systemic administration or in vitro incubation of LPS also modulated the activity of Rac1 in the heart and cardiomyocytes of mice [112,114]. Moreover, the use of knockout mice indicated that Rac1 is directly involved in LPS-induced TNF- $\alpha$ expression, the activation of NADPH oxidase, ROS production, and the stimulation of ERK1/2 and p38 MAPK pathways [112,114]. Importantly, the absence of Rac1 also reduced the loss of cardiac contractility found in endotoxemic animals [114]. Interestingly, at $4 \mathrm{~h}$ after the administration of LPS, Rac1 activity was higher in the heart of males than in cardiac samples from female mice, and this difference was abolished when the male mice were pretreated with $17 \beta$-estradiol [112]. If, on the one hand, the activity of Rac1 appears to explain at least part of the cardiac dysfunction in sepsis, on the other hand, the activation of Ras proteins and downstream ERK signaling pathways were described as the putative mechanism of cardioprotection promoted by TLR 9 in mice subjected to the CLP surgery [132].

Even though RhoA and ROCK appear to have minor effects on calcium sensitization processes in the cardiac muscle, this pathway has also been directly and indirectly involved in the pathophysiology of sepsis-induced cardiac dysfunction. For instance, the administration of fasudil reduced biochemical markers of inflammation and oxidative stress, improved the mitochondrial dynamics limiting mitochondrial fission and the phosphorylation of dynamin-related protein-1 (Drp1), and ameliorated the left ventricular function of hearts from endotoxemic mice [113]. Interestingly, the administration of LPS in rats and the incubation of cardiomyocytes with either LPS or TNF- $\alpha$ increased mitochondrial Drp1, an effect associated with augmented levels of RhoA in cells and fully inhibited by ROCK inhibition [115]. In fact, looking from the prism of cardiac dysfunction, the inactivation of the RhoA/ROCK pathway appears to be desirable and has been associated with beneficial effects (the last part of Table 2 also provides the main findings associating Rho proteins and the cardiac function in sepsis-associated models). For instance, neuregulin-1, a member of the epidermal growth factor family involved in cardiovascular function and 
disorders [133-135], attenuated the percentage of apoptotic cardiomyocytes and reduced the depression of heart function induced by LPS administration in rats, matching its ability to prevent the LPS-increased expression of RhoA and ROCK in cardiac cells [116]. However, when administered in CLP-subjected rats, intermedin 1-53, a recently discovered member of the calcitonin gene-related peptide superfamily with biological effects on heart function (for review, see [136]) prevented hypotension, improved blood flow perfusion in vital organs, and avoided the loss of contractile responses by the cardiac papillary muscle, with the last effect being associated with high levels of phosphorylation of troponin inhibitory subunits. Importantly, the authors suggested that the protective effects of intermedin 1-53 on cardiac function were significantly reduced in animals that also received the ROCK inhibitor Y-27632 [117].

\section{Rho Proteins and Their Impact on Sepsis Outside the Cardiovascular System}

Multiple organ failure is the principal outcome of septic shock [137]. Often, even those organs that are not the source of the disease are affected by the systemic inflammatory response. The kidneys, lungs, liver, gastrointestinal system, and brain are the most frequently affected throughout sepsis. It is well accepted that much of the existing damage occurs, at least in part, as a consequence of local vascular changes in response to inflammatory mediators, poor blood perfusion, and the disruption of the endothelial barrier. For instance, vascular inflammation can lead to a harmful low blood flow in the brain with acute consequences, as characterized by delirium in humans [138]. However, cognitive impairment has been described as a consequence of cerebral injury in sepsis-surviving animals [139-141]. The activation of RhoA was demonstrated as a key event for endothelial dysfunction in brain microvascular cell lines after incubation with LPS $[65,88]$. Moreover, the repeated administration of ROCK inhibitors for seven days resulted in a dose-dependent reduction in the amounts of various inflammatory mediators in the brains of rats subjected to CLP and improved the performance of the animals in cognitive tasks [139]. Interestingly, a similar improvement in learning and memory was found in CLP-subjected mice treated with the sesquiterpene $\beta$-elemene, which was associated with reduced levels of brain inflammation and decreased Rac1 activity in the mouse hippocampus [142].

Considering that most sepsis cases begin due to pneumonia [143], the lungs suffer the impact of exacerbated inflammatory processes starting in the initial stages of sepsis. Sepsis draws lungs' hyperpermeability and consequent edema, which culminate in respiratory failure. The RhoA/ROCK pathway activation seems to be important in lung inflammation, since the pharmacological inhibition of ROCK decreases neutrophil migration and lung edema in experimental models of sepsis [35,144-147]. Besides, researchers found increased levels of apoptosis in septic pulmonary tissue and pulmonary endothelial cells, and ROCK inhibition can prevent this situation $[148,149]$. Chen and co-workers suggested that the inhibition of the RhoA/ROCK pathway is an essential part of the mechanisms by which the coumarin compound esculetin improves LPS-induced inflammatory damage in the lung epithelium [150]. In recent years, microRNAs have been introduced as an experimental strategy to modulate RhoA/ROCK-mediated events. The administration of microRNA can selectively regulate the expression of diverse mRNA, modulating cell responses. In this way, the use of microRNA in sepsis and endotoxemia can reduce pulmonary inflammation by inhibiting RhoA/ROCK activation [151,152].

Another hallmark of sepsis is the disseminated intravascular coagulation and coagulopathy [153]. Interestingly, anticoagulant effects can account for at least part of the beneficial effects of ROCK inhibitors against LPS-induced lung injury [64]. It was demonstrated that unfractionated heparin reduces RhoA-GTP levels in the lungs, improving LPS-induced pulmonary injury [34]. This finding suggests that the beneficial effects of heparin in sepsis can go further than its anticoagulant properties. Platelets are critical players in hemostasis and are among the first blood cells to accumulate at an injured site. Thus, platelets can be excessively activated under endothelial malfunction, such as the one that occurs in sepsis. The overconsumption of platelets in sepsis can aggravate endothelial 
dysfunction and lead to thrombocytopenia, a condition associated with bleeding, organ dysfunction, and poor prognosis (for review, see [154]). Notably, the small Rho proteins can, directly and indirectly, be involved in the regulation of platelet aggregation $[17,155,156]$. The relevance of RhoA-mediated signaling transduction for the activity of platelets in sepsis has been suggested in studies involving both animals and human subjects. In animals, it was demonstrated that fasudil administration to mice treated with LPS reduced the rolling and adhesion of platelets to the endothelium of femoral arteries [157]. In humans, it was found that the incubation with Y-27632 was able to significantly reduce arachidonic acidinduced platelet aggregation in blood samples obtained from both septic and non-septic patients, revealing that the RhoA/ROCK pathways remain functional in platelets during the septic condition [158].

Although scarcely investigated, septic shock and experimental models of sepsis can result in a dysfunctional gastrointestinal system $[159,160]$. The regulation of the epithelial barrier and calcium sensitization by Rho proteins have been involved in both physiological and inflammation-associated disorders in the intestinal system [161-167]. The enhanced activity of RhoA was described as a determinant step for diminished epithelial resistance, leading to reduced levels of occludin and E-cadherin found in Caco-2 cells previously incubated with LPS [68]. Interestingly, the severe damage of intestinal epithelial tight junctions induced by the association of D-galactosamine and LPS in mice was prevented by ROCK inhibition, which also restored the occludin levels in the animals [168]. In guinea pigs, the intravenous injection of LPS resulted in spontaneous relaxation of the colonic muscle, a response that almost vanished with fasudil [36]. The treatment with Y-27632 also reduced apoptotic cell levels in the ileum of infant rats after the LPS challenge [169]. In addition, the degree of intestinal injury, levels of tight junction proteins, and markers of the inflammatory response were all improved in CLP-subjected mice treated with the flavanone glycoside naringin, an effect associated with the inhibition of RhoA and ROCK activities in the ileum [170]. Moreover, pleiotropic actions of simvastatin include the downregulation of both RhoA and ROCK in the intestinal tissue of CLP-subjected rats, and this effect may explain, at least in part, how simvastatin prevents the intestinal barrier disruption in septic animals [171].

The maintenance of liver function is critical for survival in sepsis (for review, see [172]). Thus, experimental studies involving the systemic effects of sepsis frequently include the measurement of hepatic biomarkers. Nevertheless, few studies have explored the biological role and the impact of the pharmacological modulation of Rho proteins in liver function in experimental models of sepsis. As described for different tissues, high levels of RhoA and Ras proteins were found in the liver of mice subjected to CLP [173]. Both fasudil and Y-27632 can prevent LPS-induced liver dysfunction in mice, resulting in reduced apoptosis, diminished rolling, the adhesion and accumulation of neutrophils, and improved blood perfusion $[37,174]$. The inhibition of ROCK also reduced proinflammatory and oxidative stress responses and improved the mitochondrial function in the liver of endotoxemic mice [175]. In contrast, the activity of Rac1 in hepatocytes was suggested as a pathway that continuously modulates inflammatory and immune responses, with both local and systemic repercussions [176].

Acute kidney injury is one of the most common clinical findings in sepsis (for review, see [177]). As previously described, the exacerbated activation of the RhoA/ROCK pathway can be involved in the maintenance of vascular responses to vasoconstrictors in the kidneys of endotoxemic rats [109]. However, studies also indicate that the modulation of Rho proteins can be essential for renal function in sepsis. For instance, evidence of an augmented activity of ROCK and protective effect of ROCK inhibitors against LPS-induced renal failure was found in mice and further associated with a proinflammatory modulation evoked by the RhoA/ROCK pathway on NF- $\mathrm{BB}$ activation [178]. Moreover, it was described that inflammatory responses of renal endothelial cells to TNF include caspase-dependent cytoskeletal changes accompanied by activation of RhoA [179]. Interestingly, the inhibition of ROCK also avoided the augmented permeability induced by TNF in mouse renal 
endothelial cells and human glomerular endothelial cells [180]. Both LPS- and adriamycininduced podocyte cytoskeleton disruption and apoptosis were associated with reduced activity and diminished expression levels of RhoA, reinforcing the putative contribution of Rho proteins for the development of renal dysfunction in sepsis [181]. Indeed, multiple Rho proteins can be involved in this process, since both LPS and NO increased the podocyte permeability to albumin in a Cdc42/Rac1-dependent manner, and the genetic depletion of Rac1 in the bone marrow-derived macrophages protect mice against the renal injury induced by LPS administration [182].

\section{Final Remarks and Conclusions}

Although many efforts have been made in basic research to prove how Rho proteins and downstream pathways contribute to the development of sepsis and septic shock, it is likely that the lack of system selective agents, perhaps acting as activators or inhibitors on distinct Rho proteins and downstream targets, is the key missing point, preventing this pathway from being adequately explored in the clinical management of sepsis. In fact, studies in this area have been overly focused on RhoA, while other small GTPases such as RhoB and RhoC, which also have regulatory effects on cardiovascular biology and may share downstream targets such as ROCK (i.e., [183-186]), remain scarcely explored in sepsis-associated experimental models. For instance, RhoB was found to be increased in macrophages, lung, liver, and kidney of LPS-treated mice, and the knockdown of this protein prevented the transcriptional activity of NF- $\mathrm{kB}$ [187].

The impaired activity of Rho-associated pathways, mainly increased activity of RhoA and the inhibition of Rac1, are listed in several studies associated with experimental sepsis models. Notably, the modulation of Rho signaling, such as with ROCK inhibitors, improved the function of, or prevented damage in multiple organs, including the lungs, liver, kidneys, and brain of animals subjected to septic insults, as illustrated in Figure 1. Although some differences existed when distinct endothelial cell lines or experimental conditions were evaluated, most experimental data indicate that Rho proteins can either be modulated by proinflammatory cascades or modulators of the inflammatory response, contributing to the endothelial barrier dysfunction existing in sepsis (Figure 2).

Although ROCK has been considered the main target of RhoA, this small GTPase can interact and modulate the activity of different intracellular components, including transcription factors, the mammalian Diaphanous homolog 1 (mDia) and profilin- 1 signaling pathway, and the type I phosphatidylinositol 4-phosphate 5-kinase isoforms, among others [188-190]. Nonetheless, the pharmacological modulation of Rho proteins has been limited to few agents that are able to inhibit only the RhoA/ROCK pathway, mainly acting on ROCK. Moreover, drugs with direct effects on Rho proteins, including but not limited to RhoA, Rac1, and Cdc42, remain to be further explored in sepsis. The association between the spread distribution, multiple roles, and few pharmacological agents has hindered the use of Rho proteins and downstream pathways as therapeutic targets. Despite the accumulated knowledge and previous clinical trials in different fields, including the cardiovascular system, the only marketed drug in the United States containing a ROCK inhibitor, named netarsudil, is an ophthalmic solution indicated for glaucoma [191]. Ripasudil has similar uses in Japan [192]. Fasudil, one of the ROCK inhibitors used in several studies included in this review, has also been used in Japan as an injectable formulation to reduce cerebral vasospasm following subarachnoid hemorrhage [193] but is still unapproved by other governmental regulatory healthy agencies. ROCK inhibitors, however, remain in focus for different diseases, including some intractable ones, such as amyotrophic lateral sclerosis $[194,195]$. Importantly, there are two isoforms of ROCK, named ROCK-I and ROCK-II, which are widely expressed [196] and are not distinguished by the currently available ROCK inhibitors. Moreover, although the MYPT-1 subunit of MLCP often appears as the only ROCK target explored in studies involving sepsis, ROCK has several other downstream targets [197] that may be druggable and remain to be explored. 
Unlike endothelial cells, in the vascular smooth muscle cells, where the RhoA/ROCK pathway acts as a calcium sensitization mechanism mediating contractile responses, most of the studies indicate that the system is depressed (Table 2). The reduced activity of Rho components decreases the inhibitory action of ROCK on myosin phosphatase, contributing to vasodilation, vasoplegia, and the hypotensive state in septic shock (Figure 3). Thus, considering the studies that explored the relationship between vascular reactivity and Rho proteins in sepsis models, the activity of the RhoA/ROCK pathway should be enhanced to increase the vascular tone during the septic insult. However, to improve endothelial function, the desired effect appears to be the inhibition of RhoA and the activation of Rac1. Together, these data clearly indicate the existence of tissue-specific differences in how sepsis-mediated events modulate the activity of Rho proteins and correlated downstream pathways. Thus, it appears that the development of strategies to adequately modulate the activity of Rho proteins and their downstream pathways during the septic insult depends on the development of innovative tools, such as drugs able to activate or inhibit Rho proteins and related pathways selectively, refinements in mRNA-based therapeutics, and continuous advances to improve our understanding about how the system works in diseased systems.

Indeed, as detailed in this review, the majority of the studies presented in the literature used only in vitro approaches, mainly cells exposed to punctual stimuli, such as LPS, proinflammatory cytokines (TNF- $\alpha$, IL-1 $\beta$ ), or bacterial components (CNF1), creating an experimental environment whose results need to be carefully evaluated and explored in more complex models before being transposed to the septic condition. Moreover, the conclusions taken from those studies that included experiments in animals were limited by:

(i) Drugs with pleiotropic or indirect effects, and unknown molecular mechanisms regarding the effects on Rho proteins and downstream targets (i.e., statins);

(ii) A lack of information regarding which Rho protein is affected in different organs during the ongoing sepsis;

(iii) A single point of evaluation;

(iv) The usage of LPS instead of more reliable experimental models of sepsis (i.e., CLP);

(iv) A lack of dose-response evaluation;

(vi) The use of acute treatments only, often as a pretreatment, missing details regarding the benefices of a post-treatment and continuous therapy, and;

(vii) The absence of toxicological and safety evaluation.

In summary, the published data showing the involvement of small GTPases in experimental models potentially associated with sepsis indicate that Rho proteins and their downstream pathways deserve further consideration as a valuable target for sepsis treatment.

Author Contributions: M.L.d.S.H. searched the literature, created the first versions of figures and tables, and prepared the initial draft. J.E.d.S.-S. worked on the conceptualization of the review, revised and edited the manuscript, including the final art and layout of figures and tables. All authors have read and agreed to the published version of the manuscript.

Funding: M.L.d.S.H is a PhD student receiving a fellowship from Coordenação de Aperfeiçoamento de Pessoal de Nível Superior (CAPES, Brazil; 88887.499191/2020-00). CAPES also supported the Graduate Program in Pharmacology of Universidade Federal de Santa Catarina (CAPES, 001). J.E.d.S.-S. received a fellowship from Conselho Nacional de Desenvolvimento Científico e Tecnológico (CNPq, 303767/2017-0).

Acknowledgments: Illustrations were created with an academic subscription of Biorender.com.

Conflicts of Interest: The authors declare no conflict of interest.

Abbreviations: CLP: cecal ligation and puncture; CNF1, cytotoxic necrotizing factor 1; Drp1, dynamin-related protein-1; eNOS, endothelial isoform of NOS; GAPs, GTPase-activating proteins; GDIs, guanine nucleotide dissociation inhibitors; GEFs, guanine nucleotide exchange factors; GPCRs, G protein-coupled receptors; IL, interleukin; iNOS, inducible isoform of NOS; LPS, lipopolysac- 
charide; MLC, myosin light chain; MLCK, myosin light chain kinase; MLCP, myosin light chain phosphatase; NF-kB, nuclear factor kappa B; NO, nitric oxide; NOS, nitric oxide synthase; ROCK, Rho-associated coiled-coil-containing protein kinase; ROS, reactive oxygen species; TLR, Toll-like receptor; TNF- $\alpha$, tumor necrosis factor $\alpha$.

\section{References}

1. Singer, M.; Deutschman, C.S.; Seymour, C.W.; Shankar-Hari, M.; Annane, D.; Bauer, M.; Bellomo, R.; Bernard, G.R.; Chiche, J.-D.; Coopersmith, C.M.; et al. The third international consensus definitions for sepsis and septic shock (sepsis-3). JAMA 2016, 315, 801-810. [CrossRef]

2. $\quad$ E Rudd, K.; Johnson, S.C.; Agesa, K.M.; Shackelford, K.A.; Tsoi, D.; Kievlan, D.R.; Colombara, D.V.; Ikuta, K.; Kissoon, N.; Finfer, S.; et al. Global, regional, and national sepsis incidence and mortality, 1990-2017: Analysis for the global burden of disease study. Lancet 2020, 395, 200-211. [CrossRef]

3. Gogos, C.A.; Drosou, E.; Bassaris, H.P.; Skoutelis, A. Pro-versus anti-inflammatory cytokine profile in patients with severe sepsis: A marker for prognosis and future therapeutic options. J. Infect. Dis. 2000, 181, 176-180. [CrossRef]

4. Rovas, A.; Sackarnd, J.; Rossaint, J.; Kampmeier, S.; Pavenstädt, H.; Vink, H.; Kümpers, P. Identification of novel sublingual parameters to analyze and diagnose microvascular dysfunction in sepsis: The Nostradamus study. Crit. Care 2021, 25, 1-14. [CrossRef]

5. Ridley, A.J. Rho GTPases and cell migration. J. Cell Sci. 2001, 114, 2713-2722. [CrossRef] [PubMed]

6. Shaw, L.M.; Ohanian, J.; Heagerty, A.M. Calcium Sensitivity and Agonist-Induced Calcium Sensitization in Small Arteries of Young and Adult Spontaneously Hypertensive Rats. Hypertension 1997, 30, 442-448. [CrossRef]

7. Uehata, M.; Ishizaki, T.; Satoh, H.; Ono, T.; Kawahara, T.; Morishita, T.; Tamakawa, H.; Yamagami, K.; Inui, J.; Maekawa, M.; et al. Calcium sensitization of smooth muscle mediated by a Rho-associated protein kinase in hypertension. Nat. Cell Biol. 1997, 389, 990-994. [CrossRef] [PubMed]

8. Birchmeier, C.; Broek, D.; Wigler, M. RAS proteins can induce meiosis in xenopus oocytes. Cell 1985, 43, 615-621. [CrossRef]

9. Aznar, S.; Lacal, J.C. Rho signals to cell growth and apoptosis. Cancer Lett. 2001, 165, 1-10. [CrossRef]

10. Bertrand, J.; Winton, M.J.; Rodriguez-Hernandez, N.; Campenot, R.B.; McKerracher, L. Application of Rho antagonist to neuronal cell bodies promotes neurite growth in compartmented cultures and regeneration of retinal ganglion cell axons in the optic nerve of adult rats. J. Neurosci. 2005, 25, 1113-1121. [CrossRef]

11. Chrzanowska, M.; Burridge, K. Rho-stimulated contractility drives the formation of stress fibers and focal adhesions. J. Cell Biol. 1996, 133, 1403-1415. [CrossRef]

12. Ridley, A.; Hall, A. The small GTP-binding protein Rho regulates the assembly of focal adhesions and actin stress fibers in response to growth factors. Cell 1992, 70, 389-399. [CrossRef]

13. Amano, M.; Nakayama, M.; Kaibuchi, K. Rho-kinase/ROCK: A key regulator of the cytoskeleton and cell polarity. Cytoskeleton 2010, 67, 545-554. [CrossRef] [PubMed]

14. Nobes, C.D.; Hall, A. Rho GTPases control polarity, protrusion, and adhesion during cell movement. J. Cell Biol. 1999, 144, 1235-1244. [CrossRef] [PubMed]

15. Tatsumoto, T.; Xie, X.; Blumenthal, R.; Okamoto, I.; Miki, T. Human Ect2 is an exchange factor for Rho GTPases, phosphorylated in G2/M phases, and involved in cytokinesis. J. Cell Biol. 1999, 147, 921-928. [CrossRef] [PubMed]

16. Jantsch-Plunger, V.; Gonczy, P.; Romano, A.; Schnabel, H.; Hamill, D.; Schnabel, R.; Hyman, A.A.; Glotzer, M. Cyk-4: A Rho family GTPase activating protein (GAP) required for central spindle formation and cytokinesis. J. Cell Biol. 2000, 149, 1391-1404. [CrossRef] [PubMed]

17. Yang, S.-A.; Carpenter, C.L.; Abrams, C.S. Rho and Rho-kinase mediate thrombin-induced phosphatidylinositol 4-phosphate 5-kinase trafficking in platelets. J. Biol. Chem. 2004, 279, 42331-42336. [CrossRef] [PubMed]

18. Kurokawa, K.; Matsuda, M. Localized RhoA activation as a requirement for the induction of membrane ruffling. Mol. Biol. Cell 2005, 16, 4294-4303. [CrossRef] [PubMed]

19. McCusker, D. Cellular self-organization: Generating order from the abyss. Mol. Biol. Cell 2020, 31, 143-148. [CrossRef]

20. Nguyen, L.K.; Kholodenko, B.N.; Von Kriegsheim, A. Rac1 and RhoA: Networks, loops and bistability. Small GTPases 2016, 9 , 316-321. [CrossRef]

21. Saha, S.; Nagy, T.L.; Weiner, O.D. Joining forces: Crosstalk between biochemical signalling and physical forces orchestrates cellular polarity and dynamics. Philos. Trans. R Soc. B Biol. Sci. 2018, 373, 145. [CrossRef]

22. Sah, V.P.; Hoshijima, M.; Chien, K.R.; Brown, J.H. Rho is required for G $\alpha q$ and $\alpha 1$-adrenergic receptor signaling in cardiomyocytes. J. Biol. Chem. 1996, 271, 31185-31190. [CrossRef]

23. Le Page, S.L.; Bi, Y.; Williams, J.A. CCK-A receptor activates RhoA through G $\alpha 12 / 13$ in NIH3T3 cells. Am. J. Physiol. Physiol. 2003, 285, 1197-1206. [CrossRef] [PubMed]

24. Clark, E.A.; King, W.G.; Brugge, J.S.; Symons, M.; Hynes, R.O. Integrin-mediated signals regulated by members of the Rho family of GTPases. J. Cell Biol. 1998, 142, 573-586. [CrossRef]

25. Wakino, S.; Hayashi, K.; Kanda, T.; Tatematsu, S.; Homma, K.; Yoshioka, K.; Takamatsu, I.; Saruta, T. Peroxisome proliferatoractivated receptor $\gamma$ ligands inhibit Rho/Rho kinase pathway by inducing protein tyrosine phosphatase SHP-2. Circ. Res. 2004, 95, 45-55. [CrossRef] 
26. Osuchowski, M.F.; Ayala, A.; Bahrami, S.; Bauer, M.; Boros, M.; Cavaillon, J.-M.; Chaudry, I.H.; Coopersmith, C.M.; Deutschman, C.; Drechsler, S.; et al. Minimum quality threshold in pre-clinical sepsis studies (MQTiPSS): An international expert consensus initiative for improvement of animal modeling in sepsis. Infection 2018, 46, 687-691. [CrossRef] [PubMed]

27. Sordi, R.; Menezes-De-Lima, O.; Della-Justina, A.M.; Rezende, E.; Assreuy, J. Pneumonia-induced sepsis in mice: Temporal study of inflammatory and cardiovascular parameters. Int. J. Exp. Pathol. 2013, 94, 144-155. [CrossRef]

28. Rittirsch, D.; Huber-Lang, M.S.; Flierl, M.A.; Ward, P.A. Immunodesign of experimental sepsis by cecal ligation and puncture. Nat. Protoc. 2008, 4, 31-36. [CrossRef] [PubMed]

29. Bosscha, V.B.N.K. A standardised and reproducible model of intra-abdominal infection and abscess formation in rats. Eur. J. Surg. 2000, 166, 963-967. [CrossRef]

30. Weinstein, W.M.; Onderdonk, A.B.; Bartlett, J.G.; Gorbach, S.L. Experimental intra-abdominal abscesses in rats: Development of an experimental model. Infect. Immun. 1974, 10, 1250-1255. [CrossRef]

31. Essler, M.; Staddon, J.M.; Weber, P.C.; Aepfelbacher, M. Cyclic AMP blocks bacterial lipopolysaccharide-induced myosin light chain phosphorylation in endothelial cells through inhibition of Rho/Rho kinase signaling. J. Immunol. 2000, 164, 6543-6549. [CrossRef] [PubMed]

32. Slotta, J.E.; Braun, O.O.; Menger, M.D.; Thorlacius, H. Fasudil, a Rho-kinase inhibitor, inhibits leukocyte adhesion in inflamed large blood vessels in vivo. Inflamm. Res. 2006, 55, 364-367. [CrossRef]

33. Zhang, J.; Yang, G.-M.; Zhu, Y.; Peng, X.-Y.; Li, T.; Liu, L.-M. Role of connexin 43 in vascular hyperpermeability and relationship to Rock1-MLC20 pathway in septic rats. Am. J. Physiol. Cell. Mol. Physiol. 2015, 309, 1323. [CrossRef]

34. Han, J.; Ding, R.; Zhao, D.; Zhang, Z.; Ma, X. Unfractionated heparin attenuates lung vascular leak in a mouse model of sepsis:Role of RhoA/Rho kinase pathway. Thromb. Res. 2013, 132, 42-47. [CrossRef]

35. Wang, Y.; Wang, X.; Liu, W.; Zhang, L. Role of the Rho/ROCK signaling pathway in the protective effects of fasudil against acute lung injury in septic rats. Mol. Med. Rep. 2018, 18, 4486-4498. [CrossRef] [PubMed]

36. Suzuki, K.; Nemoto, K.; Ninomiya, N.; Kuno, M.; Kubota, M.; Yokota, H. Fasudil, a Rho-kinase inhibitor, attenuates lipopolysaccharide-induced vascular hyperpermeability and colonic muscle relaxation in guinea pigs. J. Surg. Res. 2012, 178, 352-357. [CrossRef] [PubMed]

37. Thorlacius, K.; Slotta, J.E.; Laschke, M.W.; Wang, Y.; Menger, M.D.; Jeppsson, B.; Thorlacius, H. Protective effect of fasudil, a Rho-kinase inhibitor, on chemokine expression, leukocyte recruitment, and hepatocellular apoptosis in septic liver injury. J. Leukoc. Biol. 2006, 79, 923-931. [CrossRef] [PubMed]

38. Huang, Y.; Tan, Q.; Chen, R.; Cao, B.; Li, W. Sevoflurane prevents lipopolysaccharide-induced barrier dysfunction in human lung microvascular endothelial cells: Rho-mediated alterations of VE-cadherin. Biochem. Biophys. Res. Commun. 2015, 468, 119-124. [CrossRef] [PubMed]

39. Haidari, M.; Zhang, W.; Chen, Z.; Ganjehei, L.; Mortazavi, A.; Warier, N.; Vanderslice, P.; Dixon, R.A. Atorvastatin preserves the integrity of endothelial adherens junctions by inhibiting vascular endothelial cadherin tyrosine phosphorylation. Exp. Cell Res. 2012, 318, 1673-1684. [CrossRef]

40. Xie, K.; Wang, W.; Chen, H.; Han, H.; Liu, D.; Wang, G.; Yu, Y. Hydrogen-rich medium attenuated lipopolysaccharide-induced monocyte-endothelial cell adhesion and vascular endothelial permeability via Rho-associated coiled-coil protein kinase. Shock 2015, 44, 58-64. [CrossRef]

41. Wang, J.; Xu, J.; Zhao, X.; Xie, W.; Wang, H.; Kong, H. Fasudil inhibits neutrophil-endothelial cell interactions by regulating the expressions of GRP78 and BMPR. Exp. Cell Res. 2018, 365, 97-105. [CrossRef]

42. Sander, E.E.; Klooster, J.P.T.; Van Delft, S.; Van Der Kammen, R.A.; Collard, J.G. Rac downregulates Rho activity. J. Cell Biol. 1999, 147, 1009-1022. [CrossRef]

43. Mammoto, T.; Parikh, S.M.; Mammoto, A.; Gallagher, D.; Chan, B.; Mostoslavsky, G.; Ingber, D.E.; Sukhatme, V.P. Angiopoietin-1 requires p190 RhoGAP to protect against vascular leakage in vivo. J. Biol. Chem. 2007, 282, 23910-23918. [CrossRef]

44. Bogatcheva, N.; Zemskova, M.A.; Poirier, C.; Mirzapoiazova, T.; Kolosova, I.; Bresnick, A.R.; Verin, A.D. The suppression of myosin light chain (MLC) phosphorylation during the response to lipopolysaccharide (LPS): Beneficial or detrimental to endothelial barrier? J. Cell. Physiol. 2011, 226, 3132-3146. [CrossRef]

45. Rahman, F.A.; D'Almeida, S.; Zhang, T.; Asadi, M.; Bozoglu, T.; Bongiovanni, D.; von Scheidt, M.; Dietzel, S.; Schwedhelm, E.; Hinkel, R.; et al. Sphingosine-1-phosphate attenuates lipopolysaccharide-induced pericyte loss via activation of Rho-A and MRTF-A. Thromb. Haemost. 2021, 121, 341-350. [CrossRef]

46. Strey, A.; Janning, A.; Barth, H.; Gerke, V. Endothelial Rho signaling is required for monocyte transendothelial migration. FEBS Lett. 2002, 517, 261-266. [CrossRef]

47. Adamson, R.H.; Curry, F.E.; Adamson, G.; Liu, B.; Jiang, Y.; Aktories, K.; Barth, H.; Daigeler, A.; Golenhofen, N.; Ness, W.; et al. Rho and rho kinase modulation of barrier properties: Cultured endothelial cells and intact microvessels of rats and mice. $J$. Physiol. 2002, 539, 295-308. [CrossRef] [PubMed]

48. Waschke, J.; Burger, S.; Curry, F.-R.E.; Drenckhahn, D.; Adamson, R.H. Activation of Rac-1 and Cdc42 stabilizes the microvascular end othelial barrier. Histochem. Cell Biol. 2005, 125, 397-406. [CrossRef] [PubMed]

49. Gavard, J.; Gutkind, J.S. Protein Kinase C-related Kinase and ROCK Are required for thrombin-induced endothelial cell

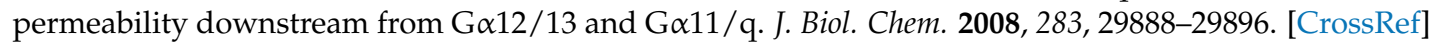


50. Bentzer, P.; Fisher, J.; Kong, H.J.; Mörgelin, M.; Boyd, J.H.; Walley, K.R.; Russell, J.A.; Linder, A. Heparin-binding protein is important for vascular leak in sepsis. Intensive Care Med. Exp. 2016, 4, 1-16. [CrossRef] [PubMed]

51. Joshi, A.D.; Dimitropoulou, C.; Thangjam, G.; Snead, C.; Feldman, S.; Barabutis, N.; Fulton, D.; Hou, Y.; Kumar, S.; Patel, V.; et al. Hsp90 inhibitors prevent LPS-induced endothelial barrier dysfunction by disrupting RhoA signaling. Am. J. Respir. Cell Mol. Biol. 2013, 50, 170-179. [CrossRef]

52. Baumer, Y.; Bürger, S.; Curry, F.E.; Golenhofen, N.; Drenckhahn, D.; Waschke, J. Differential role of Rho GTPases in endothelial barrier regulation dependent on endothelial cell origin. Histochem. Cell Biol. 2007, 129, 179-191. [CrossRef]

53. Wu, T.; Xing, J.; Birukova, A.A. Cell-type-specific crosstalk between p38 MAPK and Rho signaling in lung micro- and macrovascular barrier dysfunction induced by Staphylococcus aureus-derived pathogens. Transl. Res. 2013, 162, 45-55. [CrossRef]

54. Zheng, S.; Lin, Z.; Liu, Z.; Liu, Y.; Wu, W. Lipopolysaccharide mediates the destruction of intercellular tight junction among renal tubular epithelial cells via RhoT1/SMAD-4/JAM-3 pathway. Int. J. Med. Sci. 2018, 15, 595-602. [CrossRef]

55. Nwariaku, F.E.; Rothenbach, P.; Liu, Z.; Zhu, X.; Turnage, R.H.; Terada, L.S. Rho inhibition decreases TNF-induced endothelial MAPK activation and monolayer permeability. J. Appl. Physiol. 2003, 95, 1889-1895. [CrossRef] [PubMed]

56. Wei, F.; Liu, S.Y.; Luo, L.; Na Gu, N.; Zeng, Y.; Chen, X.Y.; Xu, S.; Zhang, D. Anti-inflammatory mechanism of ulinastatin: Inhibiting the hyperpermeability of vascular endothelial cells induced by TNF- $\alpha$ via the RhoA/ROCK signal pathway. Int. Immunopharmacol. 2017, 46, 220-227. [CrossRef] [PubMed]

57. Schlegel, N.; Waschke, J. Impaired cAMP and Rac 1 signaling contribute to TNF- $\alpha$-induced endothelial barrier breakdown in microvascular endothelium. Microcirculation 2009, 16, 521-533. [CrossRef] [PubMed]

58. Birukova, A.A.; Tian, Y.; Meliton, A.Y.; Leff, A.R.; Wu, T.; Birukov, K.G. Stimulation of Rho signaling by pathologic mechanical stretch is a "second hit" to Rho-independent lung injury induced by IL-6. Am. J. Physiol. Cell. Mol. Physiol. 2012, 302, 965-975. [CrossRef]

59. Clark, P.R.; Kim, R.K.; Pober, J.S.; Kluger, M.S. Tumor necrosis factor disrupts Claudin-5 endothelial tight junction barriers in two distinct NF-KB-dependent phases. PLoS ONE 2015, 10, e0120075. [CrossRef]

60. Hippenstiel, S.; Soeth, S.; Kellas, B.; Fuhrmann, O.; Seybold, J.; Krüll, M.; Eichel-Streiber, C.; Goebeler, M.; Ludwig, S.; Suttorp, N. Rho proteins and the p38-MAPK pathway are important mediators for LPS-induced interleukin-8 expression in human endothelial cells. Blood 2000, 95, 3044-3051. [CrossRef]

61. Schmeck, B.; Beermann, W.; van Laak, V.; Opitz, B.; Hocke, A.C.; Meixenberger, K.; Eitel, J.; Chakraborty, T.; Schmidt, G.; Barth, H.; et al. Listeria monocytogenes induced Rac1-dependent signal transduction in endothelial cells. Biochem. Pharmacol. 2006, 72, 1367-1374. [CrossRef] [PubMed]

62. Guo, F.; Tang, J.; Zhou, Z.; Dou, Y.; Van Lonkhuyzen, D.R.; Gao, C.; Huan, J. GEF-H1-RhoA signaling pathway mediates LPS-induced NF- $k B$ transactivation and IL-8 synthesis in endothelial cells. Mol. Immunol. 2012, 50, 98-107. [CrossRef] [PubMed]

63. Karki, P.; Ke, Y.; Tian, Y.; Ohmura, T.; Sitikov, A.; Sarich, N.; Montgomery, C.; Birukova, A.A. Staphylococcus aureus-induced endothelial permeability and inflammation are mediated by microtubule destabilization. J. Biol. Chem. 2019, 294, 3369-3384. [CrossRef] [PubMed]

64. Ding, R.; Zhao, D.; Li, X.; Liu, B.; Ma, X. Rho-kinase inhibitor treatment prevents pulmonary inflammation and coagulation in lipopolysaccharide-induced lung injury. Thromb. Res. 2017, 150, 59-64. [CrossRef] [PubMed]

65. He, F.; Peng, J.; Deng, X.-L.; Yang, L.-F.; Wu, L.-W.; Zhang, C.-L.; Yin, F. RhoA and NF-kB are involved in lipopolysaccharideinduced brain microvascular cell line hyperpermeability. Neuroscience 2011, 188, 35-47. [CrossRef]

66. Dong, R.; Hu, D.; Yang, Y.; Chen, Z.; Fu, M.; Wang, D.W.; Xu, X.; Tu, L. EETs reduces LPS-induced hyperpermeability by targeting GRP78 mediated Src activation and subsequent Rho/ROCK signaling pathway. Oncotarget 2017, 8, 50958-50971. [CrossRef]

67. McGown, C.C.; Brown, N.; Hellewell, P.G.; Brookes, Z.L. ROCK induced inflammation of the microcirculation during endotoxemia mediated by nitric oxide synthase. Microvasc. Res. 2011, 81, 281-288. [CrossRef]

68. Yang, T.; Wang, L.; Sun, R.; Chen, H.; Zhang, H.; Yu, Y.; Wang, Y.; Wang, G.; Yu, Y.; Xie, K. Hydrogen-rich medium ameliorates lipopolysaccharide-induced barrier dysfunction via Rhoa-Mdia1 signaling in Caco-2 cells. Shock 2016, 45, 228-237. [CrossRef]

69. Higuchi, H.; Satoh, T. Endothelin-1 induces vasoconstriction and nitric oxide release via endothelin ETB receptors in isolated perfused rat liver. Eur. J. Pharmacol. 1997, 328, 175-182. [CrossRef]

70. Whittle, B.; Lopez-Belmonte, J.; Rees, D. Modulation of the vasodepressor actions of acetylcholine, bradykinin, substance P and endothelin in the rat by a specific inhibitor of nitric oxide formation. Br. J. Pharmacol. 1989, 98, 646-652. [CrossRef]

71. Kwok, W.; Clemens, M.G. Rho-kinase activation contributes to Lps-induced impairment of endothelial nitric oxide synthase activation by endothelin-1 in cultured hepatic sinusoidal endothelial cells. Shock 2014, 42, 554-561. [CrossRef]

72. Rafikov, R.; Dimitropoulou, C.; Aggarwal, S.; Kangath, A.; Gross, C.; Pardo, D.; Sharma, S.; Jezierska-Drutel, A.; Patel, V.; Snead, C.; et al. Lipopolysaccharide-induced lung injury involves the nitration-mediated activation of RhoA. J. Biol. Chem. 2014, 289, 4710-4722. [CrossRef] [PubMed]

73. Wang, T.; Yegambaram, M.; Gross, C.; Sun, X.; Lu, Q.; Wang, H.; Wu, X.; Kangath, A.; Tang, H.; Aggarwal, S.; et al. RAC1 nitration at $\mathrm{Y} 32$ is involved in the endothelial barrier disruption associated with lipopolysaccharide-mediated acute lung injury. Redox Biol. 2021, 38, 101794. [CrossRef] [PubMed]

74. Alblas, J.; Ulfman, L.; Hordijk, P.; Koenderman, L. Activation of RhoA and ROCK are essential for detachment of migrating leukocytes. Mol. Biol. Cell 2001, 12, 2137-2145. [CrossRef] 
75. Breslin, J.W.; Sun, H.; Xu, W.; Rodarte, C.; Moy, A.B.; Wu, M.H.; Yuan, S.Y. Involvement of ROCK-mediated endothelial tension development in neutrophil-stimulated microvascular leakage. Am. J. Physiol. Circ. Physiol. 2006, 290, 741-750. [CrossRef] [PubMed]

76. Breslin, J.W.; Yuan, S.Y. Involvement of RhoA and Rho kinase in neutrophil-stimulated endothelial hyperpermeability. Am. J. Physiol. Circ. Physiol. 2004, 286, 1057-1062. [CrossRef]

77. Dorard, C.; Cseh, B.; Ehrenreiter, K.; Wimmer, R.; Varga, A.; Hirschmugl, T.; Maier, B.; Kramer, K.; Fürlinger, S.; Doma, E.; et al. RAF dimers control vascular permeability and cytoskeletal rearrangements at endothelial cell-cell junctions. FEBS J. 2019, 286, 2277-2294. [CrossRef]

78. Eriksson, A.; Cao, R.; Roy, J.; Tritsaris, K.; Wahlestedt, C.; Dissing, S.; Thyberg, J.; Cao, Y. Small GTP-binding protein Rac is an essential mediator of vascular endothelial growth factor-induced endothelial fenestrations and vascular permeability. Circulation 2003, 107, 1532-1538. [CrossRef] [PubMed]

79. Gavard, J.; Gutkind, J.S. VEGF controls endothelial-cell permeability by promoting the $\beta$-arrestin-dependent endocytosis of VE-cadherin. Nat. Cell Biol. 2006, 8, 1223-1234. [CrossRef] [PubMed]

80. Herrera, J.L.; Komatsu, M. R-Ras deficiency in pericytes causes frequent microphthalmia and perturbs retinal vascular development. J. Vasc. Res. 2021, 58, 1-15. [CrossRef] [PubMed]

81. Perrot, C.Y.; Sawada, J.; Komatsu, M. Prolonged activation of cAMP signaling leads to endothelial barrier disruption via transcriptional repression of RRAS. FASEB J. 2018, 32, 5793-5812. [CrossRef] [PubMed]

82. Vähätupa, M.; Prince, S.; Vataja, S.; Mertimo, T.; Kataja, M.; Kinnunen, K.; Marjomäki, V.; Uusitalo, H.; Komatsu, M.; Järvinen, T.A.; et al. Lack of R-Ras leads to increased vascular permeability in ischemic retinopathy. Investig. Opthalmol. Vis. Sci. 2016, 57, 4898-4909. [CrossRef] [PubMed]

83. Amerongen, G.P.V.N.; van Hinsbergh, V.W. Cytoskeletal effects of Rho-like small guanine nucleotide-binding proteins in the vascular system. Arter. Thromb. Vasc. Biol. 2001, 21, 300-311. [CrossRef]

84. Worthylake, R.A.; Lemoine, S.; Watson, J.M.; Burridge, K. RhoA is required for monocyte tail retraction during transendothelial migration. J. Cell Biol. 2001, 154, 147-160. [CrossRef]

85. Xu, W.; Wittchen, E.S.; Hoopes, S.L.; Stefanini, L.; Burridge, K.; Caron, K.M. Small GTPase Rap1A/B is required for lymphatic development and adrenomedullin-induced stabilization of lymphatic endothelial junctions. Arter. Thromb. Vasc. Biol. 2018, 38, 2410-2422. [CrossRef]

86. Yan, Z.; Wang, Z.-G.; Segev, N.; Hu, S.; Minshall, R.D.; Dull, R.O.; Zhang, M.; Malik, A.B.; Hu, G. Rab11a mediates vascular endothelial-cadherin recycling and controls endothelial barrier function. Arter. Thromb. Vasc. Biol. 2016, 36, 339-349. [CrossRef] [PubMed]

87. Vouret-Craviari, V.; Boquet, P.; Pouysségur, J.; Van Obberghen-Schilling, E. Regulation of the actin cytoskeleton by thrombin in human endothelial cells: Role of Rho proteins in endothelial barrier function. Mol. Biol. Cell 1998, 9, 2639-2653. [CrossRef] [PubMed]

88. Xiaolu, D.; Jing, P.; Fang, H.; Lifen, Y.; Liwen, W.; Ciliu, Z.; Fei, Y. Role of p115RhoGEF in lipopolysaccharide-induced mouse brain microvascular endothelial barrier dysfunction. Brain Res. 2011, 1387, 1-7. [CrossRef]

89. Zhou, Z.; Guo, F.; Dou, Y.; Tang, J.; Huan, J. Guanine nucleotide exchange factor-H1 signaling is involved in lipopolysaccharideinduced endothelial barrier dysfunction. Surgery 2013, 154, 621-631. [CrossRef] [PubMed]

90. Chen, J.; Wang, H.; Gao, C.; Liu, D.; Fan, Y.; Li, W.; Chen, Y.; Pan, S. Tetramethylpyrazine alleviates LPS-induced inflammatory injury in HUVECs by inhibiting Rho/ROCK pathway. Biochem. Biophys. Res. Commun. 2019, 514, 329-335. [CrossRef] [PubMed]

91. Qi, Y.; Liang, X.; Hu, X.; He, H.; Tang, L.; Yao, W. Tetrahydroxystilbene glucoside protects against LPS-induced endothelial dysfunction via inhibiting RhoA/ROCK signaling and F-actin remodeling. Gen. Physiol. Biophys. 2020, 39, 407-417. [CrossRef]

92. Xiao, H.; Qin, X.; Ping, D.; Zuo, K. Inhibition of Rho and Rac geranylgeranylation by atorvastatin is critical for preservation of endothelial junction integrity. PLoS ONE 2013, 8, e59233. [CrossRef]

93. Xing, J.; Wang, Q.; Coughlan, K.; Viollet, B.; Moriasi, C.; Zou, M.-H. Inhibition of AMP-activated protein kinase accentuates lipopolysaccharide-induced lung endothelial barrier dysfunction and lung injury in vivo. Am. J. Pathol. 2013, 182, 1021-1030. [CrossRef]

94. Xu, J.; Wei, G.; Wang, J.; Zhu, J.; Yu, M.; Zeng, X.; Wang, H.; Xie, W.; Kong, H. Glucagon-like peptide-1 receptor activation alleviates lipopolysaccharide-induced acute lung injury in mice via maintenance of endothelial barrier function. Lab. Investig. 2019, 99, 577-587. [CrossRef]

95. Meng, L.; Cao, H.; Wan, C.; Jiang, L. MiR-539-5p alleviates sepsis-induced acute lung injury by targeting ROCK. Folia Histochem. Cytobiol. 2020, 57, 168-178. [CrossRef] [PubMed]

96. Boer, C.; Amerongen, G.P.V.N.; Groeneveld, A.B.J.; Scheffer, G.J.; De Lange, J.J.; Westerhof, N.; Van Hinsbergh, V.W.M.; Sipkema, P. Smooth muscle F-actin disassembly and RhoA/Rho-kinase signaling during endotoxin-induced alterations in pulmonary arterial compliance. Am. J. Physiol. Cell. Mol. Physiol. 2004, 287, 649-655. [CrossRef] [PubMed]

97. Wei, C.-Y.; Huang, K.-C.; Chou, Y.-H.; Hsieh, P.-F.; Lin, K.-H.; Lin, W.-W. The Role of Rho-associated kinase in differential regulation by statins of interleukin- $1 \beta$ - and lipopolysaccharide-mediated nuclear factor $\mathrm{kB}$ activation and inducible nitric-oxide synthase gene expression in vascular smooth muscle cells. Mol. Pharmacol. 2005, 69, 960-967. [CrossRef] 
98. Büyükafşar, K.; Arikan, O.; Ark, M.; Kubat, H.; Ozveren, E.; Arıkan, O. Upregulation of Rho-kinase (ROCK-2) expression and enhanced contraction to endothelin-1 in the mesenteric artery from lipopolysaccharide-treated rats. Eur. J. Pharmacol. 2004, 498, 211-217. [CrossRef] [PubMed]

99. Bernardelli, A.K.; Da Silva, R.D.C.D.A.; Corrêa, T.; Da Silva-Santos, J.E. Vasoplegia in sepsis depends on the vascular system, vasopressor, and time-point: A comparative evaluation in vessels from rats subjected to the cecal ligation puncture model. Can. J. Physiol. Pharmacol. 2016, 94, 1227-1236. [CrossRef]

100. El-Awady, M.S.H.; Smirnov, S.V.; Watson, M.L. Voltage-independent calcium channels mediate lipopolysaccharide-induced hyporeactivity to endothelin-1 in the rat aorta. Am. J. Physiol. Circ. Physiol. 2009, 296, 1408-1415. [CrossRef]

101. Da Silva-Santos, J.E.; Chiao, C.-W.; Leite, R.; Webb, R.C. The Rho-A/Rho-kinase pathway is up-regulated but remains inhibited by cyclic guanosine monophosphate-dependent mechanisms during endotoxemia in small mesenteric arteries. Crit. Care Med. 2009, 37, 1716-1723. [CrossRef] [PubMed]

102. Liao, M.-H.; Shih, C.-C.; Tsao, C.-M.; Chen, S.-J.; Wu, C.-C. RhoA/Rho-kinase and nitric oxide in vascular reactivity in rats with endotoxaemia. PLoS ONE 2013, 8, e56331. [CrossRef] [PubMed]

103. Liang, J.-L.; Yang, G.-M.; Li, T.; Liu, L.-M. Effects of interleukin-1 $\beta$ on vascular reactivity after lipopolysaccharide-induced endotoxic shock in rabbits and its relationship with PKC and Rho kinase. J. Cardiovasc. Pharmacol. 2013, 62, 84-89. [CrossRef] [PubMed]

104. Zhao, H.; Kuang, L.; He, J.; Zhang, Z.; Zheng, D.; Duan, C.; Zhu, Y.; Wu, Y.; Zhang, J.; Peng, X.; et al. Role of tumor necrosis factor- $\alpha$ in vascular hyporeactivity following endotoxic shock and its mechanism. J. Trauma Acute Care Surg. 2019, 87, 1346-1353. [CrossRef]

105. Bivalacqua, T.J.; Champion, H.C.; Usta, M.F.; Cellek, S.; Chitaley, K.; Webb, R.C.; Lewis, R.L.; Mills, T.M.; Hellstrom, W.J.G.; Kadowitz, P.J. RhoA/Rho-kinase suppresses endothelial nitric oxide synthase in the penis: A mechanism for diabetes-associated erectile dysfunction. Proc. Natl. Acad. Sci. USA 2004, 101, 9121-9126. [CrossRef]

106. Chitaley, K.; Webb, R.C. Nitric oxide induces dilation of rat aorta via inhibition of Rho-kinase signaling. Hypertension 2002, 39, 438-442. [CrossRef]

107. Reddi, B.A.; Beltrame, J.F.; Young, R.L.; Wilson, D.P. Calcium desensitisation in late polymicrobial sepsis is associated with loss of vasopressor sensitivity in a murine model. Intensive Care Med. Exp. 2015, 3, 36. [CrossRef]

108. de Souza, P.; Guarido, K.L.; Scheschowitsch, K.; Da Silva, L.M.; Werner, M.F.; Assreuy, J.; Da Silva-Santos, J.E. Impaired vascular function in sepsis-surviving rats mediated by oxidative stress and Rho-kinase pathway. Redox Biol. 2016, 10, 140-147. [CrossRef]

109. Guarido, K.L.; Gonçalves, R.P.M.; Júnior, A.G.; da Silva-Santos, J.E. Increased activation of the Rho-A/Rho-kinase pathway in the renal vascular system is responsible for the enhanced reactivity to exogenous vasopressin in endotoxemic rats. Crit. Care Med. 2014, 42, 461-471. [CrossRef]

110. Tseng, T.; Chen, M.; Liu, C.-H.; Pang, C.; Hsu, Y.; Lee, T.J.F. Induction of endothelium-dependent constriction of mesenteric arteries in endotoxemic hypotensive shock. Br. J. Pharmacol. 2016, 173, 1179-1195. [CrossRef]

111. Soliman, H.; Craig, G.P.; Nagareddy, P.; Yuen, V.G.; Lin, G.; Kumar, U.; McNeill, J.H.; MacLeod, K. Role of inducible nitric oxide synthase in induction of RhoA expression in hearts from diabetic rats. Cardiovasc. Res. 2008, 79, 322-330. [CrossRef]

112. Zhu, H.; Shan, L.; Peng, T. Rac1 mediates sex difference in cardiac tumor necrosis factor- $\alpha$ expression via NADPH oxidaseERK1/2/p38 MAPK pathway in endotoxemia. J. Mol. Cell. Cardiol. 2009, 47, 264-274. [CrossRef]

113. Preau, S.; Delguste, F.; Yu, Y.; Remy-Jouet, I.; Richard, V.; Saulnier, F.; Boulanger, E.; Neviere, R. Endotoxemia engages the RhoA kinase pathway to impair cardiac function by altering cytoskeleton, mitochondrial fission, and autophagy. Antioxid. Redox Signal. 2016, 24, 529-542. [CrossRef] [PubMed]

114. Zhang, T.; Lu, X.; Beier, F.; Feng, Q. Rac1 activation induces tumour necrosis factor- $\alpha$ expression and cardiac dysfunction in endotoxemia. J. Cell. Mol. Med. 2010, 15, 1109-1121. [CrossRef] [PubMed]

115. Shen, Y.; Shi, Y.; Chen, G.; Wang, L.; Zheng, M.; Jin, H.; Chen, Y.-Y. TNF- $\alpha$ induces Drp1-mediated mitochondrial fragmentation during inflammatory cardiomyocyte injury. Int. J. Mol. Med. 2018, 41, 2317-2327. [CrossRef] [PubMed]

116. Kang, W.; Cheng, Y.; Zhou, F.; Wang, L.; Zhong, L.; Li, H.T.; Wang, X.; Dang, S. Neuregulin-1 protects cardiac function in septic rats through multiple targets based on endothelial cells. Int. J. Mol. Med. 2019, 44, 1255-1266. [CrossRef] [PubMed]

117. Zhu, Y.; Wu, H.; Wu, Y.; Zhang, J.; Peng, X.; Zang, J.; Xiang, X.; Liu, L.; Li, T. Beneficial effect of Intermedin1-53 in septic shock rats. Shock 2016, 46, 557-565. [CrossRef] [PubMed]

118. Jafri, S.M.; LaVine, S.; Field, B.E.; Ahorozian, M.T.; Carlson, R.W. Left ventricular diastolic function in sepsis. Crit. Care Med. 1990, 18, 709-714. [CrossRef]

119. Poelaert, J.; Declerck, C.; Vogelaers, D.; Colardyn, F.; A Visser, C. Left ventricular systolic and diastolic function in septic shock. Intensive Care Med. 1997, 23, 553-560. [CrossRef]

120. Natanson, C.; Fink, M.P.; Ballantyne, H.K.; MacVittie, T.J.; Conklin, J.J.; E Parrillo, J. Gram-negative bacteremia produces both severe systolic and diastolic cardiac dysfunction in a canine model that simulates human septic shock. J. Clin. Investig. 1986, 78, 259-270. [CrossRef]

121. Gonçalves, R.P.; Guarido, K.L.; Assreuy, J.; da Silva-Santos, J.E. Gender-specific differences in the in situ cardiac function of endotoxemic rats detected by pressure-volume catheter. Shock 2014, 42, 415-423. [CrossRef] [PubMed]

122. Habimana, R.; Choi, I.; Cho, H.J.; Kim, D.; Lee, K.; Jeong, I. Sepsis-induced cardiac dysfunction: A review of pathophysiology. Acute Crit. Care 2020, 35, 57-66. [CrossRef] 
123. Chang, J.; Xie, M.; Shah, V.R.; Schneider, M.; Entman, M.L.; Wei, L.; Schwartz, R.J. Activation of Rho-associated coiled-coil protein kinase 1 (ROCK-1) by caspase-3 cleavage plays an essential role in cardiac myocyte apoptosis. Proc. Natl. Acad. Sci. USA 2006, 103, 14495-14500. [CrossRef]

124. Talukder, M.A.H.; Elnakish, M.T.; Yang, F.; Nishijima, Y.; Alhaj, M.A.; Velayutham, M.; Hassanain, H.H.; Zweier, J.L. Cardiomyocyte-specific overexpression of an active form of Rac predisposes the heart to increased myocardial stunning and ischemia-reperfusion injury. Am. J. Physiol. Circ. Physiol. 2013, 304, 294-302. [CrossRef] [PubMed]

125. He, Q.; Lapointe, M.C. Interleukin-1 $\beta$ regulation of the human brain natriuretic peptide promoter involves Ras-, Rac-, and p38 kinase-dependent pathways in cardiac myocytes. Hypertension 1999, 33, 283-289. [CrossRef] [PubMed]

126. Hattori, T.; Shimokawa, H.; Higashi, M.; Hiroki, J.; Mukai, Y.; Tsutsui, H.; Kaibuchi, K.; Takeshita, A. Long-term inhibition of Rho-kinase suppresses left ventricular remodeling after myocardial infarction in mice. Circulation 2004, 109, 2234-2239. [CrossRef] [PubMed]

127. Thorburn, J.; Xu, S.; Thorburn, A. MAP kinase- and Rho-dependent signals interact to regulate gene expression but not actin morphology in cardiac muscle cells. EMBO J. 1997, 16, 1888-1900. [CrossRef]

128. Hines, W.A.; Thorburn, A. Ras and Rho are required for G $\alpha$ q-induced hypertrophic gene expression in neonatal rat cardiac myocytes. J. Mol. Cell. Cardiol. 1998, 30, 485-494. [CrossRef]

129. Satoh, M.; Ogita, H.; Takeshita, K.; Mukai, Y.; Kwiatkowski, D.J.; Liao, J.K. Requirement of Rac1 in the development of cardiac hypertrophy. Proc. Natl. Acad. Sci. USA 2006, 103, 7432-7437. [CrossRef]

130. Aikawa, R.; Komuro, I.; Yamazaki, T.; Zou, Y.; Kudoh, S.; Zhu, W.; Kadowaki, T.; Yazaki, Y. Rho family small G proteins play critical roles in mechanical stress-induced hypertrophic responses in cardiac myocytes. Circ. Res. 1999, 84, 458-466. [CrossRef]

131. Derangeon, M.; Bourmeyster, N.; Plaisance, I.; Pinet-Charvet, C.; Chen, Q.; Duthe, F.; Popoff, M.R.; Sarrouilhe, D.; Hervé, J.-C. RhoA GTPase and F-actin dynamically regulate the permeability of Cx43-made channels in rat cardiac myocytes. J. Biol. Chem. 2008, 283, 30754-30765. [CrossRef] [PubMed]

132. Gao, M.; Ha, T.; Zhang, X.; Wang, X.; Liu, L.; Kalbfleisch, J.; Singh, K.; Williams, D.; Li, C. The Toll-like receptor 9 ligand, CpG oligodeoxynucleotide, attenuates cardiac dysfunction in polymicrobial sepsis, involving activation of both phosphoinositide 3 kinase/Akt and extracellular-signal-related kinase signaling. J. Infect. Dis. 2013, 207, 1471-1479. [CrossRef]

133. Baliga, R.R.; Pimental, D.R.; Zhao, Y.-Y.; Simmons, W.W.; Marchionni, M.A.; Sawyer, D.B.; Kelly, R.A. NRG-1-induced cardiomyocyte hypertrophy. Role of PI-3-kinase, p70S6K, and MEK-MAPK-RSK. Am. J. Physiol. Circ. Physiol. 1999, 277, $2026-2037$. [CrossRef] [PubMed]

134. Liu, X.; Gu, X.; Li, Z.; Li, X.; Li, H.; Chang, J.; Chen, P.; Jin, J.; Xi, B.; Chen, D.; et al. Neuregulin-1/erbB-activation improves cardiac function and survival in models of ischemic, dilated, and viral cardiomyopathy. J. Am. Coll. Cardiol. 2006, 48, 1438-1447. [CrossRef] [PubMed]

135. Rentschler, S.; Zander, J.; Meyers, K.; France, D.; Levine, R.; Porter, G.; Rivkees, S.A.; Morley, G.E.; Fishman, G.I. Neuregulin-1 promotes formation of the murine cardiac conduction system. Proc. Natl. Acad. Sci. USA 2002, 99, 10464-10469. [CrossRef]

136. Bell, D.; McDermott, B. Intermedin (adrenomedullin-2): A novel counter-regulatory peptide in the cardiovascular and renal systems. Br. J. Pharmacol. 2008, 153, 247-262. [CrossRef]

137. Lagu, T.; Rothberg, M.B.; Shieh, M.-S.; Pekow, P.S.; Steingrub, J.S.; Lindenauer, P.K. Hospitalizations, costs, and outcomes of severe sepsis in the United States 2003 to 2007. Crit. Care Med. 2012, 40, 754-761. [CrossRef]

138. Pfister, D.; Siegemund, M.; Dell-Kuster, S.; Smielewski, P.; Rüegg, S.; Strebel, S.P.; Marsch, S.C.; Pargger, H.; Steiner, L.A. Cerebral perfusion in sepsis-associated delirium. Crit. Care 2008, 12, 63. [CrossRef]

139. Jianjun, Z.; Baochun, Z.; Limei, M.; Lijun, L. Exploring the beneficial role of ROCK inhibitors in sepsis-induced cerebral and cognitive injury in rats. Fundam. Clin. Pharmacol. 2021, in press. [CrossRef]

140. Barichello, T.; Martins, M.; Reinke, A.; Constantino, L.; Machado, R.; Valvassori, S.; Moreira, J.; Quevedo, J.; Dal-Pizzol, F. Behavioral deficits in sepsis-surviving rats induced by cecal ligation and perforation. Braz. J. Med Biol. Res. 2007, 40, 831-837. [CrossRef]

141. Leite, F.B.; Prediger, R.D.; Silva, M.V.; De Sousa, J.B.; Carneiro, F.P.; Gasbarri, A.; Tomaz, C.; Queiroz, A.J.; Martins, N.T.; Ferreira, V.M. Role of nicotine on cognitive and behavioral deficits in sepsis-surviving rats. Brain Res. 2013, 1507, 74-82. [CrossRef] [PubMed]

142. Pan, C.; Si, Y.; Meng, Q.; Jing, L.; Chen, L.; Zhang, Y.; Bao, H. Suppression of the RAC1/MLK3/p38 signaling pathway by $\beta$-elemene alleviates sepsis-associated encephalopathy in mice. Front. Neurosci. 2019, 13, 358. [CrossRef] [PubMed]

143. Angus, D.C.; Linde-Zwirble, W.T.; Lidicker, J.; Clermont, G.; Carcillo, J.; Pinsky, M.R. Epidemiology of severe sepsis in the United States: Analysis of incidence, outcome, and associated costs of care. Crit. Care Med. 2001, 29, 1303-1310. [CrossRef]

144. Hasan, Z.; Palani, K.S.H.; Zhang, S.; Lepsenyi, M.; Hwaiz, R.; Rahman, M.; Syk, I.; Jeppsson, B.; Thorlacius, H. Rho kinase regulates induction of T-cell immune dysfunction in abdominal sepsis. Infect. Immun. 2013, 81, 2499-2506. [CrossRef]

145. Palani, K.S.H.; Rahman, M.; Hasan, Z.; Zhang, S.; Qi, Z.; Jeppsson, B.; Thorlacius, H. Rho-kinase regulates adhesive and mechanical mechanisms of pulmonary recruitment of neutrophils in abdominal sepsis. Eur. J. Pharmacol. 2012, 682, 181-187. [CrossRef]

146. Tasaka, S.; Koh, H.; Yamada, W.; Shimizu, M.; Ogawa, Y.; Hasegawa, N.; Yamaguchi, K.; Ishii, Y.; Richer, S.E.; Doerschuk, C.M.; et al. Attenuation of endotoxin-induced acute lung injury by the Rho-associated kinase inhibitor, Y-27632. Am. J. Respir. Cell Mol. Biol. 2005, 32, 504-510. [CrossRef] 
147. Li, Y.; Wu, Y.; Wang, Z.; Zhang, X.-H.; Wu, W.-K. Fasudil attenuates lipopolysaccharide-induced acute lung injury in mice through the Rho/Rho kinase pathway. Med. Sci. Monit. 2010, 16, 112-118.

148. Cinel, I.; Ark, M.; Dellinger, P.; Karabacak, T.; Tamer, L.; Cinel, L.; Michael, P.; Hussein, S.; Parrillo, J.E.; Kumar, A.; et al. Involvement of Rho kinase (ROCK) in sepsis-induced acute lung injury. J. Thorac. Dis. 2012, 4, 30-39. [CrossRef] [PubMed]

149. Liu, H.; Chen, X.; Han, Y.; Li, C.; Chen, P.; Su, S.; Zhang, Y.; Pan, Z. Rho kinase inhibition by fasudil suppresses lipopolysaccharideinduced apoptosis of rat pulmonary microvascular endothelial cells via JNK and p38 MAPK pathway. Biomed. Pharmacother. 2014, 68, 267-275. [CrossRef]

150. Chen, T.; Guo, Q.; Wang, H.; Zhang, H.; Wang, C.; Zhang, P.; Meng, S.; Li, Y.; Ji, H.; Yan, T. Effects of esculetin on lipopolysaccharide (LPS)-induced acute lung injury via regulation of RhoA/Rho Kinase/NF-кB pathways in vivo and in vitro. Free Radic. Res. 2015, 49, 1459-1468. [CrossRef]

151. Siddiqui, M.R.; Akhtar, S.; Shahid, M.; Tauseef, M.; McDonough, K.; Shanley, T.P. miR-144-mediated inhibition of ROCK1 protects against LPS-induced lung endothelial hyperpermeability. Am. J. Respir. Cell Mol. Biol. 2019, 61, 257-265. [CrossRef] [PubMed]

152. Chen, H.; Hu, X.; Li, R.; Liu, B.; Zheng, X.; Fang, Z.; Chen, L.; Chen, W.; Min, L.; Hu, S. LncRNA THRIL aggravates sepsis-induced acute lung injury by regulating miR-424/ROCK2 axis. Mol. Immunol. 2020, 126, 111-119. [CrossRef]

153. Iba, T.; Levy, J.H.; Warkentin, T.E.; Thachil, J.; Van Der Poll, T.; Levi, M. Diagnosis and management of sepsis-induced coagulopathy and disseminated intravascular coagulation. J. Thromb. Haemost. 2019, 17, 1989-1994. [CrossRef] [PubMed]

154. Vardon-Bounes, F.; Ruiz, S.; Gratacap, M.-P.; Garcia, C.; Payrastre, B.; Minville, V. Platelets are critical key players in sepsis. Int. J. Mol. Sci. 2019, 20, 3494. [CrossRef] [PubMed]

155. Aburima, A.; Walladbegi, K.; Wake, J.D.; Naseem, K.M. cGMP signaling inhibits platelet shape change through regulation of the RhoA-Rho kinase-MLC phosphatase signaling pathway. J. Thromb. Haemost. 2017, 15, 1668-1678. [CrossRef]

156. Nishioka, H.; Horiuchi, H.; Tabuchi, A.; Yoshioka, A.; Shirakawa, R.; Kita, T. Small GTPase Rho regulates thrombin-induced platelet aggregation. Biochem. Biophys. Res. Commun. 2001, 280, 970-975. [CrossRef]

157. Slotta, J.E.; Braun, O.Ö.; Menger, M.D.; Thorlacius, H. Central role of Rho kinase in lipopolysaccharide-induced platelet capture on venous endothelium. J. Investig. Med. 2008, 56, 720-725. [CrossRef]

158. Reddi, B.A.; Iannella, S.M.; O'Connor, S.N.; Deane, A.M.; Willoughby, S.R.; Wilson, D.P. Attenuated platelet aggregation in patients with septic shock is independent from the activity state of myosin light chain phosphorylation or a reduction in Rho kinase-dependent inhibition of myosin light chain phosphatase. Intensive Care Med. Exp. 2015, 3, 1-17. [CrossRef] [PubMed]

159. Spates, S.T.; Cullen, J.J.; Ephgrave, K.S.; Hinkhouse, M.M. Effect of endotoxin on canine colonic motility and transit. J. Gastrointest. Surg. 1998, 2, 391-398. [CrossRef]

160. Yoseph, B.P.; Klingensmith, N.J.; Liang, Z.; Breed, E.; Burd, E.M.; Mittal, R.; Dominguez, J.A.; Petrie, B.; Ford, M.L.; Coopersmith, C.M. Mechanisms of intestinal barrier dysfunction in sepsis. Shock 2016, 46, 52-59. [CrossRef]

161. Du, L.; Kim, J.J.; Shen, J.; Dai, N. Crosstalk between inflammation and ROCK/MLCK signaling pathways in gastrointestinal disorders with intestinal hyperpermeability. Gastroenterol. Res. Pract. 2016, 2016, 7374197. [CrossRef] [PubMed]

162. Haydont, V.; Bourgier, C.; Vozenin-Brotons, M.-C. Rho/ROCK pathway as a molecular target for modulation of intestinal radiation-induced toxicity. Br. J. Radiol. 2007, 80, 32-40. [CrossRef] [PubMed]

163. Jin, Y.; Blikslager, A.T. The regulation of intestinal mucosal barrier by myosin light chain kinase/Rho kinases. Int. J. Mol. Sci. 2020, 21, 3550. [CrossRef] [PubMed]

164. Williams, J.A.; Chen, X.; Sabbatini, M.E. Small G proteins as key regulators of pancreatic digestive enzyme secretion. Am. J. Physiol. Metab. 2009, 296, 405-414. [CrossRef] [PubMed]

165. Ares, G.; Buonpane, C.; Sincavage, J.; Yuan, C.; Wood, D.R.; Hunter, C.J. Caveolin 1 is associated with upregulated claudin 2 in necrotizing enterocolitis. Sci. Rep. 2019, 9, 1-14. [CrossRef]

166. Gong, M.C.; Iizuka, K.; Nixon, G.; Browne, J.P.; Hall, A.; Eccleston, J.F.; Sugai, M.; Kobayashi, S.; Somlyo, A.V. Role of guanine nucleotide-binding proteins-ras-family or trimeric proteins or both-In $\mathrm{Ca}^{2+}$ sensitization of smooth muscle. Proc. Natl. Acad. Sci. USA 1996, 93, 1340-1345. [CrossRef]

167. Buonpane, C.; Yuan, C.Y.; Wood, D.R.; Ares, G.; Klonoski, S.C.; Hunter, C.J. ROCK1 inhibitor stabilizes E-cadherin and improves barrier function in experimental necrotizing enterocolitis. Am. J. Physiol. Liver Physiol. 2020, 318, 781-792. [CrossRef]

168. Wu, F.; Li, H.; Zhang, H.; Liao, Y.; Ren, H.; Wu, J.; Zheng, D. Phosphorylated-myosin light chain mediates the destruction of small intestinal epithelial tight junctions in mice with acute liver failure. Mol. Med. Rep. 2021, 23, 1-7. [CrossRef]

169. Ozdemir, D.; Cilaker, S.; Tugyan, K.; Dagdelen, M.K.; Derinoz, O.; Guneli, E. The effect of Rho kinase inhibitor Y-27632 on endotoxemia-induced intestinal apoptosis in infant rats. J. Mol. Histol. 2011, 43, 81-87. [CrossRef]

170. Li, Z.; Gao, M.; Yang, B.; Zhang, H.; Wang, K.; Liu, Z.; Xiao, X.; Yang, M. Naringin attenuates MLC phosphorylation and NF-кB activation to protect sepsis-induced intestinal injury via RhoA/ROCK pathway. Biomed. Pharmacother. 2018, 103, 50-58. [CrossRef]

171. Wang, Y.; Wang, X.; Yang, W.; Zhao, X.; Zhang, R. Effect of simvastatin on the intestinal Rho/ROCK signaling pathway in rats with sepsis. J. Surg. Res. 2018, 232, 531-538. [CrossRef]

172. Yan, J.; Li, S.; Li, S. The role of the liver in sepsis. Int. Rev. Immunol. 2014, 33, 498-510. [CrossRef]

173. Pizzino, G.; Bitto, A.; Pallio, G.; Irrera, N.; Galfo, F.; Interdonato, M.; Mecchio, A.; De Luca, F.; Minutoli, L.; Squadrito, F.; et al. Blockade of the JNK signalling as a rational therapeutic approach to modulate the early and late steps of the inflammatory cascade in polymicrobial sepsis. Mediat. Inflamm. 2015, 2015, 1-7. [CrossRef] [PubMed] 
174. Slotta, J.E.; Laschke, M.W.; Menger, M.D.; Thorlacius, H. Rho-kinase signalling mediates endotoxin hypersensitivity after partial hepatectomy. BJS 2008, 95, 976-984. [CrossRef]

175. Ding, R.; Han, J.; Zhao, D.; Hu, Z.; Ma, X. Pretreatment with Rho-kinase inhibitor ameliorates lethal endotoxemia-induced liver injury by improving mitochondrial function. Int. Immunopharmacol. 2016, 40, 125-130. [CrossRef]

176. Pohlmann, S.; Scheu, S.; Ziegler, V.; Schupp, N.; Henninger, C.; Fritz, G. Hepatic Rac1 GTPase contributes to liver-mediated basal immune homeostasis and LPS-induced endotoxemia. Biochim. Biophys. Acta Bioenerg. 2018, 1865, 1277-1292. [CrossRef]

177. Zarjou, A.; Agarwal, A. Sepsis and acute kidney injury. J. Am. Soc. Nephrol. 2011, 22, 999-1006. [CrossRef]

178. Meyer-Schwesinger, C.; Dehde, S.; Von Ruffer, C.; Gatzemeier, S.; Klug, P.; Wenzel, U.O.; Stahl, R.A.K.; Thaiss, F.; Meyer, T.N. Rho kinase inhibition attenuates LPS-induced renal failure in mice in part by attenuation of NF- $\mathrm{kB}$ p65 signaling. Am. J. Physiol. Physiol. 2009, 296, 1088-1099. [CrossRef]

179. Wu, X.; Guo, R.; Chen, P.; Wang, Q.; Cunningham, P.N. TNF induces caspase-dependent inflammation in renal endothelial cells through a Rho- and myosin light chain kinase-dependent mechanism. Am. J. Physiol. Physiol. 2009, 297, 316-326. [CrossRef] [PubMed]

180. Xu, C.; Wu, X.; Hack, B.K.; Bao, L.; Cunningham, P.N. TNF causes changes in glomerular endothelial permeability and morphology through a Rho and myosin light chain kinase-dependent mechanism. Physiol. Rep. 2015, 3, 12636. [CrossRef]

181. Huang, Z.; Zhang, L.; Chen, Y.; Zhang, H.; Yu, C.; Zhou, F.; Zhang, Z.; Jiang, L.; Li, R.; Ma, J.; et al. RhoA deficiency disrupts podocyte cytoskeleton and induces podocyte apoptosis by inhibiting YAP/dendrin signal. BMC Nephrol. 2016, 17, 1-12. [CrossRef]

182. Mashmoushi, A.K.; Oates, J.C. Lipopolysaccharide induces inducible nitric oxide synthase-dependent podocyte dysfunction via a hypoxia-inducible factor $1 \alpha$ and cell division control protein 42 and Ras-related C3 botulinum toxin substrate 1 pathway. Free Radic. Biol. Med. 2015, 84, 185-195. [CrossRef]

183. Hoeppner, L.H.; Sinha, S.; Wang, Y.; Bhattacharya, R.; Dutta, S.; Gong, X.; Bedell, V.; Suresh, S.; Chun, C.Z.; Ramchandran, R.; et al. RhoC maintains vascular homeostasis by regulating VEGF-induced signaling in endothelial cells. J. Cell Sci. 2015, 128, 3556-3568. [CrossRef]

184. Vega, F.M.; Ridley, A.J. The RhoB small GTPase in physiology and disease. Small GTPases 2018, 9, 384-393. [CrossRef] [PubMed]

185. Wojciak-Stothard, B.; Zhao, L.; Oliver, E.; Dubois, O.; Wu, Y.; Kardassis, D.; Vasilaki, E.; Huang, M.; Mitchell, J.A.; Harrington, L.S.; et al. Role of RhoB in the regulation of pulmonary endothelial and smooth muscle cell responses to hypoxia. Circ. Res. 2012, 110, 1423-1434. [CrossRef]

186. Zhao, Z.; Liu, K.; Tian, X.; Sun, M.; Wei, N.; Zhu, X.; Yang, H.; Wang, T.; Jiang, G.; Chen, K. Effects of RhoC downregulation on the angiogenesis characteristics of myeloma vascular endothelial cells. Cancer Med. 2019, 8, 3502-3510. [CrossRef]

187. Wang, X.H.; Wang, Y.; Diao, F.; Lu, J. RhoB is involved in lipopolysaccharide-induced inflammation in mouse in vivo and in vitro. J. Physiol. Biochem. 2012, 69, 189-197. [CrossRef]

188. Kim, J.; Islam, R.; Cho, J.Y.; Jeong, H.; Cap, K.; Park, Y.; Hossain, A.J.; Park, J. Regulation of RhoA GTPase and various transcription factors in the RhoA pathway. J. Cell. Physiol. 2018, 233, 6381-6392. [CrossRef]

189. Lu, Q.; Lu, L.; Chen, W.; Chen, H.; Xu, X.; Zheng, Z. RhoA/mDia-1/profilin-1 signaling targets microvascular endothelial dysfunction in diabetic retinopathy. Graefe's Arch. Clin. Exp. Ophthalmol. 2015, 253, 669-680. [CrossRef]

190. Weernink, P.A.O.; Meletiadis, K.; Hommeltenberg, S.; Hinz, M.; Ishihara, H.; Schmidt, M.; Jakobs, K.H. Activation of type I phosphatidylinositol 4-phosphate 5-kinase isoforms by the Rho GTPases, RhoA, Rac1, and Cdc42. J. Biol. Chem. 2004, 279, 7840-7849. [CrossRef]

191. Dasso, L.; Al-Khaled, T.; Sonty, S.; Aref, A.A. Profile of netarsudil ophthalmic solution and its potential in the treatment of open-angle glaucoma: Evidence to date. Clin. Ophthalmol. 2018, 12, 1939-1944. [CrossRef]

192. Tanihara, H.; Kakuda, T.; Sano, T.; Kanno, T.; Gunji, R. Safety and efficacy of ripasudil in Japanese patients with glaucoma or ocular hypertension: 12-month interim analysis of ROCK-J, a post-marketing surveillance study. BMC Ophthalmol. 2020, $20,1-11$. [CrossRef]

193. Tanaka, K.; Minami, H.; Kota, M.; Kuwamura, K.; Kohmura, E. Treatment of cerebral vasospasm with intra-arterial fasudil hydrochloride. Neurosurgery 2005, 56, 214-223. [CrossRef]

194. Clinical Trials. gov. Inhibition of Rho Kinase (ROCK) with Fasudil as Disease-Modifying Treatment for ALS. Available online: https: / / www.clinicaltrials.gov/ct2/show / NCT03792490?term=Rho-kinase\&draw=5\&rank=7 (accessed on 25 May 2021).

195. Koch, J.C.; Kuttler, J.; Maass, F.; Lengenfeld, T.; Zielke, E.; Bähr, M.; Lingor, P. Compassionate use of the ROCK inhibitor fasudil in three patients with amyotrophic lateral sclerosis. Front. Neurol. 2020, 11, 173. [CrossRef]

196. Nakagawa, O.; Fujisawa, K.; Ishizaki, T.; Saito, Y.; Nakao, K.; Narumiya, S. ROCK-I and ROCK-II, two isoforms of Rho-associated coiled-coil forming protein serine/threonine kinase in mice. FEBS Lett. 1996, 392, 189-193. [CrossRef]

197. Feng, Y.; Lograsso, P.V.; Defert, O.; Li, R. Rho kinase (ROCK) inhibitors and their therapeutic potential. J. Med. Chem. 2015, 59, 2269-2300. [CrossRef] 